\title{
KONSEP PATRILINEAL DALAM FILM BERLATAR BUDAYA BATAK TOBA
}

\author{
Suryanto \\ ${ }^{1}$ Program Studi Televisi Dan Film \\ ${ }^{2}$ Universitas Potensi Utama \\ ryan.potensiutama@gmail.com
}

\begin{abstract}
ABSTRAK
Penelitian ini berjudul "Konsep Patrilineal Dalam Film Berlatar Budaya Batak". Film berlatar budaya Batak Toba yang diambil untuk penelitian adalah lima film antara lain film Sinamot, Toba Dreams, Mursala, Anak Sasada dan Mutiara Dari Toba dikarena kelima film tersebut sangat menarik dan menggambarkan adat istiadat Batak Toba. Penelitian ini bertujuan untuk mengungkap fenomena-fenomena film berlatar budaya Batak Toba pada masyarakat Batak Toba mengungkapkan pandangan masyarakat Batak Toba terhadap film Sinamot, Toba Dreams, Mursala, Anak Sasada dan Mutiara Dari Toba. Metode penelitian dan teori yang digunakan teori Semiotika Roland Barthes yang mengungkap berdasarkan penanda, petanda dan mitos serta teori resepsi Hans Robert Jauss dan Wolfgang Iser untuk mengetahui pandangan masyarakat terhadap kelima film yang berlatar budaya Batak Toba. Hasil yang diperoleh dalam penelitian bahwa fenomena film baik secara teks narasi dan sinematik yang dimunculkan dalam film berlatar budaya Batak Toba melaui penanda dan petanda dan membentuk mitos yang bermakna pewarisan tradisi. Film menggambarkan sebuah Dalihan Na Tolu, Sistem patrilineal, tradisi merantau adat Batak Toba dan sistem kepercayaan masyarakat Batak Toba yang telah diwariskan secara turun menurun. Kemudian pandangan masyarakar Batak Toba
\end{abstract}

Kata kunci : Fenomena, Masyarakat Batak Toba dan Film berlatar budaya Batak Toba

\begin{abstract}
This research is entitled "Patrilineal Concepts in Film Based on Batak Culture". Films based on Toba Batak culture taken for research are five films including Sinamot, Toba Dreams, Mursala, Sasada Children and Pearls from Toba because the five films are very interesting and illustrate Toba Batak customs. This study aims to uncover the phenomena of the film based on the Toba Batak culture in the Toba Batak community expressing the views of the Toba Batak community towards Sinamot, Toba Dreams, Mursala, Sasada Children and Pearls from Toba. The research methods and theories used by Roland Barthes's Semiotic theory which reveal based on markers, markers and myths and reception theory Hans Robert Jauss and Wolfgang Iser to find out the views of the community on the five films set in Toba Batak culture. The results obtained in the study that the phenomena of the film both narrative and cinematic texts that were raised in films set in Toba Batak culture through markers and markers and formed a myth that meant inheritance of tradition. The film depicts a Dalihan Na Tolu, the patrilineal system, the tradition of migrating the Toba Batak customs and the belief system of the Toba Batak community which has been inherited from time to time. Then the views of the Toba Batak community
\end{abstract}

Keywords: Phenomenon, Toba Batak Society and Film set in Toba Batak culture

\section{PENDAHULUAN}

Film merupakan salah satu alat untuk menyampaikan berbagai pesan kepada khalayak melalui sebuah media cerita. Film juga merupakan medium ekspresi artistik sebagai suatu alat bagi para pekerja seniman dan insan perfilman dalam rangka mengutarakan gagasan-gagasan dan ide cerita. Secara esensial dan substansial film memiliki power yang akan berimplikasi terhadap komunikan masyarakat (Wibowo, 2006: 196). Film sejak kemunculan pertamanya telah menjadi fenomena yang menarik, serta memiliki kombinasi secara bahasa suara dan bahasa gambar. Hal ini dapat diterima dengan baik oleh orang yang menonton. Fenomena adalah rangkaian peristiwa serta bentuk keadaan yang diamati dan dinilai lewat kacamata ilmiah atau lewat disiplin ilmu tertentu. 
Masyarakat Batak Toba merupakan satu suku bangsa yang sejak dulu hingga sekarang menjunjung tinggi adat dan nilai kekeluargaan (kekerabatan) serta rasa solidaritas. Sifat-sifat mereka yang khas, gaya dan kepribadiannnya yang merupakan gambaran yang melukiskan secara keseluruhan kehidupan suku Batak, baik daerah perantauan maupun daerah asal. Kebiasaan gotong royong yang diajarkan di lingkungan keluarga menjadikan sifat keuletan, kerja keras dan kesungguhan mencerminkan kepribadian yang ada didalam diri mereka (Sianipar, 2002: 12).

Konsep yang sangat mendasar dari sistem kekerabatan ini adalah marga. Semua anggota dari satu marga memakai satu identitas yang dibubuhkan sesudah nama kecilnya, nama marga itu merupakan pertanda bahwa orang-orang yang menggunakannya masih mempunyai kakek yang sama. Secara logis tidak dapat terperinci rentetan leluhur atau kakek yang menghubungkan orangorang se-marga dengan kakek yang sama, namun ada suatu keyakinan bahwa orang-orang yang menggunakan nama marga tersebut terjalin oleh hubungan darah (Vergouwen,1986:25). Penentuan kedudukan yang ditimbulkan berdasarkan marga membuat sesorang akan terikat kepada adat istiadat yang disebut dengan Dalihan Na Tolu (Tungku Nan Tiga).

Kehidupan di masyarakat Batak Toba terdapat fenomena-fenomena yang sesuai dengan peristiwa dan aturan hukum adat Batak Toba seperti Dalihan Na Tolu, Sistem patrilineal Batak Toba, Sistem kepercayaan dan Tradisi merantau masyarakat Batak Toba. Fenomena-fenomena sosial masyarakat Batak Toba, film berlatar budaya Batak Toba yakni : Film Sinamot sutradara Amirullah Harahap (2015), Mursala sutradara Viva Westi (2013), Mutiara Dari Toba sutradara William Atapary (2013), Toba Dreams sutradara Benni Setiawan (2013) dan Anak Sasada sutradara Pontyanus Gea (2011). Adapun setiap masing-masing film tersebut terdapat fenomena yang berbeda mengenai budaya Batak Toba yaitu Film Sinamot berdurasi satu jam dengan bergenre drama dengan jenis film indiedanberlatar kehidupan adat istiadat Batak dengan sutradara Amirullah Harahap. Kisah cinta anak muda Batak yang terhalang oleh ketidaksesuaian Sinamot dari pihak perempuan dan terjadinya tawar menawar tentang harga Sinamot tinggi. Fenomena dalam film Sinamot adalah Ketidaksesuaian Sinamot dapat menggagalkan kesepakatan dalam melakukan perkawinan. Sehubungan dengan itu, Sinamot begitu sangat penting dalam tradisi Batak Toba. Hal ini dikarenakan dalam adat Batak Toba Sinamot harus ada apabila Sinamot tidak ada maka perkawinan tidak sah secara adat dan dapat gagalnya perkawinan.

Selanjutnya film Mursala yang di sutradara Viva Westi dan berlatar budaya Batak Toba mengenai aturan aturan pemilihan pasangan dalam perkawinan sesama marga dan bercerita perjuangan dari seorang pemuda Batak bernama Anggiat yang merantau ke Jakarta yang menjadi seorang pengacara dan dibanggakan orang tuanya. Ayah dan Ibu Anggiat mengharapkan Anggiat menikah dengan pariban-nya. Akan tetapi di Jakarta Anggiat telah memiliki wanita berdarah Batak yang dicintainya yaitu Clarisa seorang presenter televisi. Fenomena aturan pemilihan pasangan dalam perkawinan sesama marga muncul ketika ternyata Anggiat dan Clarisa terjebak dengan aturan adat Batak, yang membuat mereka tidak dapat menikah yang disebabkan satu saudara atau sesama marga yang sama. Sedangkan dalam film Mutiara dari Tobaberdurasi seratus menit dengan bergenre drama dengan jenis film indie yang menggunakan bahasa Batak Tobadanberlatar kehidupan adat istiadat Batak serta wisata Danau Toba dengan sutradara William Atapary. Film ini berhubungan dengan kebudayaan Batak Toba yang harus dijaga dan dilestarikan dan berisi tentang kisah cinta (romantisme) dan persahabatan. Fenomena dari film Mutiara dari Toba adalah Kebudayaan adat Batak Toba.

Film Toba Dreams merupakan salah satu film yang bertemakan tentang sejarah biografi seorang tentara prajurit yang bernama Sersan TB. Secara singkat film ini berlatarkan budaya Batak Toba yang merupakan keturunan dari Sersan TB itu sendiri. Film ini menceritakan dalam mendidik anak-anaknya dengan peraturan yang dibawanya dari profesinya sebagai anggota prajurit tentara yang keras dan disiplin sehingga ia sering sekali berargumen dengan anak sulungnya yang bernama Ronggur. Sikap watak Ronggur hampir tidak ada bedanya dengan Sersan TB membuat Ronggur dan ayahnya sering beradu pendapat dan menimbulkan perdebatan yang cukup menegangkan. Selain itu, film ini juga menyampaikan secara lebih lugas mengenai falsafah hidup sebagai orang Batak Toba yang secara langsung menjadi acuan dalam film untuk lebih menjelaskan bagaimana kehidupan suku Batak Toba dalam kesehariannya. Fenomena yang cukup dominan dalam film Toba Dream adalah falsafah hidup orang Batak Toba merupakan prinsip hidup serta pandangan hidup 
yang sudah menjadi kebiasaan dalam kehidupan sehari-hari Masyarakat Batak Toba. Mereka mengedapankan budaya, adat istiadat, dan falsafah hidup itu sendiri.

Selanjutnya film Anak Sasada adalah film mengisahkan tentang kemiskinan dan pendidikan orang di desa yang harus merantau ke Kota Medan yang disutadarai Pontyanus Gea. Anak Sasada yang dikemas dalam dialog bahasa Batak Toba, menggambarkan realitas kemiskinan perdesaan melalui tokoh Sabungan. Ia meninggalkan kampung halaman untuk mencari kehidupan yang lebih baik. Ternyata tanah perantauan tidak seperti dugaan Sabungan yang terlibat masalah dengan kelompok penjahat dan menjumpai nasib tragis. Anak Sasada dalam masyarakat Batak Toba adalah anak laki-laki satu-satunya yang menjadi tanggung jawab atas keluarganya. Fenomena yang terdapat dalam film Anak Sasada adalah permasalahan kemiskinan dan pendidikan yang menyebabkan menrantau ke Kota dalam kehidupan sehari-hari yang terjadi ditengah masyarakat Batak Toba.

Berdasarkan fenomena-fenomena yang terdapat pada 5 (lima) film tersebut, alasan peneliti mengangkat 5 (lima) film karena film-film tersebut sangat dominan menampilkan mengenai aturan hukum adat Batak Toba yang sangat dijaga dan dilestarikan serta menggambarkan realitas kehidupan masyarakat Batak Toba. Kemudian fenomena-fenomena dalam film berlatar budaya Batak Toba akan mengungkapkan adanya keterkaitan dengan masyarakat Batak Toba dan di hubungkan langsung dalam pandangan masyakarat Batak Toba. Oleh sebab itu, baik secara realitas masyarakat Batak Toba dan teks film terhadap fenomena film berlatar budaya Batak Toba begitu sangat unik dan menarik untuk dikaji.

\section{STUDI LITERATUR}

\section{II.1. Teori Semiotika (Roland Barthes)}

Semiotika dapat diartikan kajian mengenai tanda dan cara tanda-tanda tersebut bekerja. Daniel Chandler mengatakan, "The shortest definition is that it is the study of signs" (Vera, 2014: 2). Kriyanto mengemukakan bahwa semiotika merupakan studi tentang tanda dan segala yang berhubungan dengannya, cara fungsinya, hubunganya dengan tanda-tanda lain, pengirimannya dari penerimaan oleh mereka yang menggunakannya (Kriyanto, 2010: 265).

Film merupakan bidang kajian yang amat relavan bagi analisis semiotika. Film dibangun dengan tanda semata-mata, dalam film juga menggunakan tanda-tanda ikonis, yaitu tanda-tanda yang menggambarkan sesuatu. Gambar yang dinamis dalam film merupakan ikonis bagi realitas yang dinotasikannya (Sobur, 2009: 128). Film umumnya dibangun dengan banyak tanda, salah satu point penting dalam film adalah gambar dan suara. Film menuturkan cerita dengan cara khususnya sendiri seperti mediumnya, cara pembuatannya dengan kamera hingga dipertunjukkan dengan proyektor dan layar.

Hal-hal yang memiliki arti simbolis tidak terhitung jumlahnya adalah sebuah film. Kebanyakkan film memberikan setting arti simbolik yang penting sekali. Setiap bentuk cerita sebuah simbol adalah sesuatu yang konkret yang mewakili atau melambangkan. Penelitian ini membahas bagian tiap scene atau gambar dan symbol yang dimunculkan dalam film berlatar budaya Batak Toba yang diyakini memiliki makna.

Teori semiotika merupakan teori turunan dari teori bahasa Saussure. Roland Barthes Mengungkapkan bahwa bahasa merupakan sebuah bahasa sistem tanda yang mencerminkan asumsi-asumsi dari masyarakat tertentu dalam waktu tertentu (Sobur, 2006: 63). Sebagaiman pandangan Saussure, Barthes meyakini bahwa hubungan antara penanda dan petanda tidak terbentuk secara alamiah, melainkan secara arbiter (Vera, 2014: 27). Barthes menekankan pada tataran denotative dan mengembangkan sistem penandaan pada tingkat konotatif. Selain itu, Barthes juga melihat aspek lain dari penandaan yaitu "mitos" yang menandai masyarakat.

Denotasi merujuk pada apa yang diyakini akal sehat atau orang banyak, makna yang teramati dari sebuah tanda. Konotasi adalah istilah yang digunakan Roland Barthes untuk menjelaskan salah satu cara kerja tanda pada signifikasi tahap kedua. Hal ini menjelaskan interaksi yang terjadi ketika tanda betemu dengan perasaan atau emosi dari pengguna dan nilai-nilai dalam budaya mereka. Barthes menjelaskan bahwa cara kedua dalam cara kerja tanda signifikasi tahap kedua adalah mitos. Mitos adalah sebuah cerita dimana suatu kebudayaan menjelaskan atau 
memahami beberapa aspek dari realitas atau alam. Mitos menurut Barthes merupakan sebuah budaya cara berfikir tentang sesuatu, cara mengonseptualisasi atau memahami hal tersebut.

Adapun cara kerja atau langkah-langkah model Semiotik Roland Barthes dalam mengenalisis makna dapat dipetakan sebagai berikut :

Tabel 1. Peta Tanda Roland Barthes

\begin{tabular}{|c|c|c|}
\hline $\begin{array}{l}\text { 1. Signifier } \\
\text { (Penanda) }\end{array}$ & $\begin{array}{l}\text { 2. Signified } \\
\text { (Petanda) }\end{array}$ & \\
\hline \multicolumn{3}{|c|}{ Denotatif Sign (Tanda Denotatif) } \\
\hline \multicolumn{2}{|c|}{$\begin{array}{l}\text { 4. CONNOTATIF SIGNIFIER } \\
\text { (PENANDA KONOTATIF) }\end{array}$} & $\begin{array}{l}\text { 5. CONNOTATIF SIGNIFIED } \\
\text { (PETANDA KONOTATIF) }\end{array}$ \\
\hline
\end{tabular}

(Sumber : Alex Sobur, 2003)

Dari peta Barthes tersebut terlihat bahwa tanda denotatif (3) terdiri atas penanda (1) dan petanda (2). Akan tetapi, pada saat bersamaan, tanda denotatif adalah juga penanda konotatif (4). Dari penanda konotatif akan memunculkan petanda konotatif yang kemudian akan melandasi munculnya tanda konotatif (Alex Sobur, $2004: 69$ ).

Tanda yang terdapat dalam film berlatar budaya Batak Toba akan diungkap menggunakan analisis semiotika. Hal itu dikarenakan semiotika dianggap mampu untuk menjelaskan berbagai hal yang tampak dipermukaan bahkan semiotika juga mampu membongkar makna-makna tersembunyi sehingga kedalaman dan keluasaan informasi sangat menentukan sejauh mana informasi diperoleh.

Makna-makna yang didapat dalam film berlatar budaya Batak Toba secara tidak langsung akan menjelaskan atau membongkar fenomena-fenomena yang terdapat pada film berlatar budaya Batak Toba yakni film Sinamot, Mutiara dari Toba, Mursala, Toba Dreams, dan Anak Sasada. Maka, untuk menganalisis film berlatar budaya Batak Toba penulis menggunakan model analisis Roland Barthes.

\section{II.2 Resepsi}

Menurut Segers, estetika resepsi secara ringkas dapat disebut sebagai suatu ajaran yang menyelidiki teks sastra berdasarkan reaksi pembaca yang nyata (real) dan yang mungkin terhadap karya sastra. Dengan memperhatikan watak teks yang sastrawi, sebuah hipotesis kerja diambil berdasarkan pembaca yang memutuskan suatu teks sastra dianggap bermutu "sastra" atau tidak (Dian Swandayani dan Nuning Catur Sri Wilujeng, 2010: 1).

Resepsi sastra merupakan aliran sastra yang meneliti teks sastra dengan mempertimbangkan pembaca selaku pemberi sambutan atau tanggapan. Dalam memberikan sambutan dan tanggapan tentunya dipengaruhi oleh faktor ruang, waktu, dan golongan sosial. Secara definitif resepsi sastra berasal dari kata recipere (Latin), reception (Inggris), yang diartikan sebagai penerimaan atau penyambutan pembaca. Dalam arti luas resepsi diartikan sebagai pengolahan teks, cara-cara pemberian makna terhadap karya sehingga dapat memberikan respon terhadapnya. Respon yang dimaksudkan tidak dilakukan antara karya dengan seorang pembaca, melainkan pembaca sebagai proses sejarah, pembaca dalam periode tertentu (Ratna, 2009: 165).

Hans Robert Jauss menjadi pemikir yang terkenal mengenai nasib pembaca dalam teori resepsi. Jauss dan Iser sama-sama memandang bahwa penafsiran bukan sebagai penemuan makna objektif atau makna yang tersembunyi dalam teks (Nuryatin 1998: 133). Kata kunci dari konsep yang diperkenalkan Jauss adalah Rezeptions und wirkungsästhetik atau estetika tanggapan dan efek. Menurutnya, pembacalah yang menilai, menikmati, menafsirkan, dan memahami karya sastra. Pembaca dalam kondisi demikianlah yang mampu menentukan nasib dan peranannya dari segi sejarah sastra dan estetika. Pada estetika resepsi (aesthetics of reception) dapat dideskripsikan sebagai kerja yang mengumpulkan teks kesusasteraan berdasarkan kemungkinan tanggapan pembaca. Resepsi estetik dapat disinonimkan dengan tanggapan sastra (literary response) dan bisa diartikan pembaca memberikan tanggapan (Janus, 1985: 1).

Resepsi sebuah karya dengan pemahaman dan penilaiannya tidak dapat diteliti lepas dari rangka sejarahnya seperti yang terwujud dalam horison harapan pembaca masing-masing. Dalam kaitannya dengan pembaca, karya sastra mendapat makna dan fungsinya. Pengalaman pembaca 
yang dimaksud mengindikasikan bahwa teks karya sastra menawarkan efek yang bermacam-macam kepada pembaca yang bermacam-macam pula dari sisi pengalamannya pada setiap periode atau zaman pembacaannya. Pembacaan yang beragam dalam periode waktu yang berbeda akan menunjukkan efek yang berbeda pula. Pengalaman pembaca akan mewujudkan orkestrasi yang padu antara tanggapan baru pembacanya dengan teks yang membawanya hadir dalam aktivitas pembacaan pembacanya. Dalam hal ini, kesejarahan sastra tidak bergantung pada organisasi faktafakta literer tetapi dibangun oleh pengalaman kesastraan yang dimiliki pembaca atas pengalaman sebelumnya (Jauss 1983: 21).

Menurut Jauss (1983: 13) yang menjadi perhatian utama dalam teori resepsi adalah pembaca karya sastra di antara jalinan segitiga pengarang, karya sastra, dan masyarakat pembaca. Pembaca mempunyai peranan aktif bahkan mempunyai kekuatan pembentuk sejarah. Dalam pandangan Jauss (1983: 12) suatu karya sastra dapat diterima pada suatu masa tertentu berdasarkan suatu horizon penerimaan tertentu yang diharapkan. Metode resepsi didasarkan pada teori yang menyatakan bahwa karya sastra sejak awal kemunculannya selalu mendapatkan tanggapan dari pembacanya. Apresiasi pembaca pertama terhadap suatu karya sastra akan dilanjutkan melalui tanggapan-tanggapan dari pembaca berikutnya (Jauss 1983: 14). Berbeda dengan Jauss, Isser menekankan teori resepsinya pada efek, kesan, dari sebuah teks yang dirasakan oleh pembaca secara langsung. Pembaca dalam hal ini dengan kemampuan imajinasinya akan langsung melakukan resepsi terhadap sebuah teks dan menghubungkannya dengan realitas yang ada.

Pradopo (2007: 210-211) mengemukakan bahwa penelitian resepsi dapat dilakukan dengan dua cara, Pertama, teori yang mempelajari penerimaan pembaca sejak sebuah karya muncul hingga kini (diakronik). Kedua, teori yang mempelajari tanggapan pembaca secara umum terhadap teks itu pada kekiniannya (sinkronik). Pertama, teori resepsi lebih menekankan pada tanggapan pembaca dari waktu ke waktu. Oleh karena itu lebih bersifat resepsi historis. Sedangkan yang kedua lebih menekankan pada penelitian terhadap suatu karya kini. Teori yang pertama dikembangkan oleh Jauss, seperti yang dijelaskan di atas, dan teori yang kedua diprakarsai oleh Isser.

Teori resepsi dalam penelitian ini menggunakan metode sinkronis dan diakronis untuk dapat memberikan pemahaman kepada pembaca atau masyarakat Batak Toba mengenai fenomena film berlatar budaya Batak Toba baik secara teks film dan konteks terhadap film berlatar budaya Batak Toba dengan memberi sebuah pertanyaan-pertanyaan.

\section{PEMBAHASAN}

Film merupakan produk kebudayaan manusia yang dianggap berdampak besar bagi masyarakat karena merupakan salah satu bentuk seni, sumber hiburan dan alat ampuh untuk mendidik serta mengindoktrinasi para penontonnya. Melalui pengalaman mental dan budaya yang dimilikinya, penonton berperan aktif secara sadar maupun tidak sadar untuk memahami sebuah film (Pratista, 2008:3). Film dapat berdampak negatif maupun positif terhadap penontonya, Irawanto menyatakan bahwa :

Banyak peneletian film dipahami secara linear, artinya film selalu mempengaruhi dan membentuk masyarakat berdasarkan muatan pesan (massage) dibaliknya, tanpa berlaku sebaliknya. Kritik yang muncul terhadap perspektif ini didasarkan atas argument bahwa film adalah potret masyarakat diman film itu dibuat. Film selalu merekam realitas yang tumbuh dan berkembang dalam masyarakat, dan kemudian memproyeksikannya keatas layar (Sobur, 2009:127).

Fenomena budaya yang diangkat ke dalam film yang tumbuh dan berkembang dalam masyarakat Batak Toba telah diproyeksikan kepada film Sinamot sutradara Amirullah Harahap, film Toba Dreams sutradara Benni Setiawan, film Mursala sutradara Viva Westi, film Anak Sasada sutrarada Pontyanus Gea, dan film Mutiara dari Toba sutradara William Atapary. Film ini dibentuk oleh dua unsur pembentuk film yakni : unsur naratif dan unsur sinematik. Pratista menyatakan bahwa kedua unsur tersebut saling berinteraksi dan berkesinambungan satu sama lain untuk membentuk sebuah film. Film tidak akan terbentuk jika tidak memiliki kedua unsur tersebut, dapat dikatakan bahwa unsur naratif adalah bahan atau materi yang akan diolah, sedangkan unsur sinematik adalah cara dan gaya untuk mengolahnya. Berikut merupakan bagan dari unsur pembentuk film : 


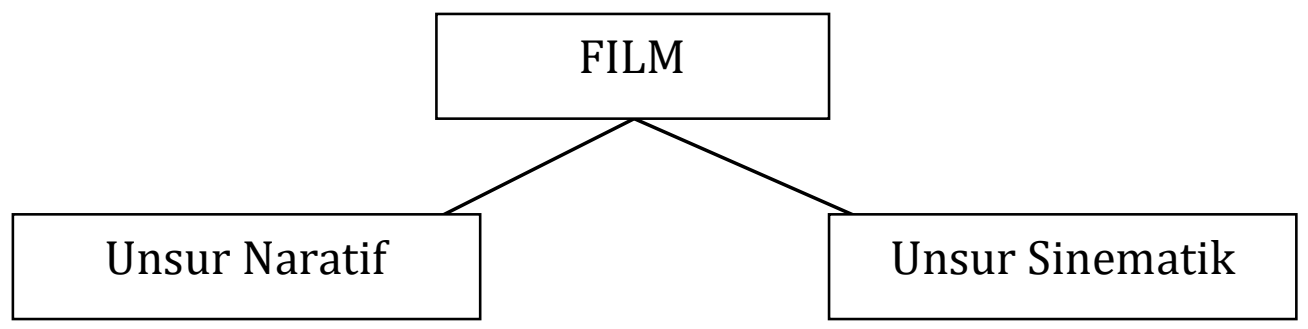

\section{Editing \\ Suara \\ Gambar 1. Hubungan Film dengan Unsur Naratif dan Sinematik}

(Sumber : Pratista, 2008)

Pada gambar 1 menjelaskan hubungan film dengan unsur naratif dan unsur sinematik. Kedua unsur tersebut dapat diuraikan sebagai berikut :

\section{A. Unsur Naratif}

Cerita sebuah film mengandung unsur naratif dalam bentuk rangkaian peristiwa yang saling berhubungan satu sama lain dan terkait logika sebab akibat yang terjadi dalam ruang dan waktu. Cerita pada film Sinamot, Toba Dreams, Mursala, Anak Sasada, dan Mutiara dari Toba memunculkan akibat aksi, tindakan dari pelaku cerita yang memotivasi terjadinya kesatuan peristiwa yang memuat unsur-unsur plot. Plot merupakan rangkaian peristiwa yang disajikan secara audio visual dalam film (Pratista, 2008: 33). Sedangkan plot menurut Haig P. Manoogian adalah :

Alur cerita (plot) adalah penjabaran dari cerita sebuah film, terdiri dari rentetan-rentetan kejadian bermotivasi dan berhubungan secara sebab akibat. Struktur menuunjuk kepada kejadiankejadian dari plot tersebut (Paransi, 2005: 8).

Plot sebagian besar dituturkan dalam pola linear dimana urutan waktu berjalan sesuai urutan aksi peristiwa tanpa adanya interupsi waktu yang signifikan. Elemen-elemen naratif yang membantu jalannya sebuah alur cerita adalah pelaku cerita yang menjadi motivator utama yang menjalankan alur cerita seperti tokoh protagonis (utama/jagoan) dan antagonis (pendukung/musuh/rival). Permasan atau konflik, dapat diartikan seperti penghalang tokoh protagonis untuk mencapai tujuannya. Tujuan yang ingin dicapai pelaku cerita, bisa berupa fisik seperti mengalahkan musuh atau dapat berupa non fisik seperti kebahagian dan sebagainya (Pratista, 2005: 44).

Pelaku cerita sebagai penggerak cerita yang menjalankan alur naratif sejak awal hingga akhir cerita. Tokoh utama dapat diistilahkan sebagai pihak protagonis sedangkan karakter pendukung dapat berada dipihak protagonis atau antagonis sebagai pemicu adanya konflik, dalam film. Pada film yang berlatar Budaya Batak Toba yakni film Sinamot, Toba Dreams, Mursala, Anak Sasada dan Mutiara Dari Toba memiliki jenis plot linear yaitu alur cerita mulai dari awal sampai akhir cerita bergerak lurus.

Hal ini terdapat plot pada film Sinamot ketika awal cerita. Niko berperan sebagai tokoh pemuda Batak yang berjuang dan berusaha untuk memenuhi biaya Sinamot tinggiuntuk wanita yang dia cintai yaitu Maya. Niko berusaha memenuhi biaya Sinamottinggi dikarenakan keluarga perempuan wajib menentukan besaran Sinamot untuk merayakan perkawinan seorang perempuan Batak yang identik dengan kemewahan dan perempuan yang dia cintai adalah memiliki keserjanaan. Namun persoalan atau pertentangan muncul ketika Ayah Maya memberikan waktu 6 (enam) bulan kepada Niko untuk menepati atau memenuhi Sinamot yang sudah disepakati bersama sebelumnya. Apabila Niko tidak bisa memenuhi Sinamot dengan tinggi atau lewat dari waktu yang sudah ditentukan maka Ayah Maya akan mengawinkan dengan laki-laki Batak yang sanggup memenuhi Sinamot tersebut. Pada akhir cerita dalam film Sinamot Niko dan Maya tidak dapat atau gagal kawin yang disebabkan tidak bisa memenuhi Sinamot tersebut. Hal ini terdapat sebuah aturan Batak Toba mengenai Dalihan Na Tolu, Sistem patrilineal dan sistem kepercayaan yang ada dalam film Sinamot.

Kemudian lain halnya dengan film Toba Dreams yang tokoh utamanya adalah Ronggur. Ronggur adalah seorang pemuda yang berasal dari Jakarta tapi Ayahnya berasal dari tanah Batak 
yaitu Balige. Pada awal cerita Ronggur berperan sebagai tokoh pemuda Batak yang berasal dari Jakarta dan pergi pulang kampung ke tanah Batak yaitu Balige yang dekat dengan Danau Toba untuk mengikuti Ayahnya yang ingin hidup dengan tenang dan damai mengandalkan uang pensiunan tentara. Namun, persoalan atau pertentangan muncul ketika Ronggur menolak, ia ingin membuktikan bahwa selama ini ayahnya salah memilih jalan hidup. Hal ini terdapat makna Dalihan $\mathrm{Na}$ Tolu dan sistem patrilineal, Maka ketika Ronggur, anak sulungnya menjadi pemberontak dalam keluarga, terjadilah konflik mendalam antara ayah dan anak. Pada akhir cerita atau plot pada film Toba Dreams Sersan TB menangis melihat anaknya Ronggur tertembak dan meninggal dunia. Film Toba Dreams juga terdapat sebuah fenomena budaya Batak Toba yang paling dominan yakni Sistem patrilineal, hal ini digambarkan pada Sersan TB yang memiliki peranan penting dalam sebuah keluarganya dan memiliki sistem kepercayaan dalam adat Batak Toba.

Sedangkan dalam film Mursala dengan tokoh utamanya adalah Anggiat Simbolon. Anggiat adalah seorang pemuda berasal dari Desa Sorkam Kabupaten Tapanuli Tengah. Anggiat berperan sebagai tokoh pemuda Batak yang berasal dari Desa Sorkam dan merantau ke Kota Jakarta untuk menggapai cita-citanya sebagai pengacara. Perjuangan Anggiat tidak sia-sia karena di Jakarta Anggiat berhasil menjadi pengacara yang sukses. Selain sukses dalam berkarir, Anggiat juga sudah mempunyai kekasih yang juga berketurunan Batak yaitu Clarisa Saragih. Namun, persoalan atau pertentangan muncul karena Anggiat dan Clarisa memiliki marga yang termasuk dalam parna (kumpulan marga tidak dapat menikah). Sedangkan inang (ibu Anggiat) sendiri ingin putranya menikah dengan Pariban-nya yaitu Taruli Sinaga yang berada dikampungnya. Pada akhirnya Anggiat jatuh cinta terhadap Taruli yang saling mencintai. Film Mursala sangat tergambar pada adat Batak Toba mulai dari Dalihan Na Tolu, Sistem patrlineal, sistem kepercayaan dan tradisi merantau yang menjadi suatu ciri khas masyarakat Batak Toba.

Selanjutnya pada film Anak Sasada dengan tokoh utamanya adalah Sabungan. Sabungan adalah seorang pemuda yang berasal dari Balige. Diawal cerita atau plot Sabungan berperan sebagai tokoh pemuda Batak yang berasal dari Balige dan merantau ke Kota Medan untuk mencari pekerjaan demi keluarganya yang ada dikampung halamanya. Status sebagai anak lelaki satu-satunya dalam keluarga membentuk Sabungan menjadi pribadi manja. Ia kerap mengabaikan ucapan orangtua terutama jika berkaitan dengan pekerjaan. Orang tua diperlakukan tidak baik untuk memenuhi kegiatannya berjudi dan minum minuman keras setiap hari.Akibat kalah berjudi Sabungan berniat menjual ulos-ulos milik ibunya. Ia mengambil semua ulos yang disimpan ibunya di lemari. Tangis ibunya tak mampu menghentikan Sabungan. Beruntung, seorang tetangga yang mendengar keributan di rumah mereka mendatangi dan mencegah niat Sabungan. Sabungan memutuskan untuk merantau ke Kota Medan untuk mencari kerja agar dapat merubah hidupnya tetapi pekerjaan Sabungan tidak sesuai dengan harapannya. Pada akhir cerita dalam film Anak Sasada Sabungan yang berada dirumah sakit akibat berantam dengan kelompok penjahat akhirnya berjumpa dengan adik kandungnya yaitu Rotua. Pada film Anak Sasada lebih memfokuskan pada tradisi merantau yang menjadi pokok permasalahannya dalam sebuah cerita serta diiringi dengan sistem kepercayaan Batak Toba dan sistem patrilineal. Hal ini dikarenakan aturan Batak Toba yang tidak boleh ditinggalkan dan diihilangkan sepenuhnya, karena aturan Batak Toba saling berhubungan satu sama lainnya.

Konflik adalah dasar drama berupa pertentangan yang dialami tokoh sebagai respon atas timbulnya kekuatan-kekuatan dramatis (Dietrich, 1953: 78). Film Anak Sasada sendiri bergendre drama, yang pada dasarnya drama berarti pencerminan dalam kehidupan manusia di masyarakat. Menurut Mark drama yang baik biasanya memiliki konflik yang selalu terkait dengan tema alur. Tema terbangun melalui alur yang kuat dan alur tersebut dapat menarik perhatian karena tersusun dengan jalinan konflik-konflik yang matang dan terarah serta tersebar secara merata dalam setiap alur tersebut (Mark, 1985:85). Tujuan yang ingin dicapai oleh tokoh utama dalam film Anak Sasada yaitu Sabungan adalah mendapatkan perkerjaan yang lebih baik didaerah perantauan dan membahagiakan keluargnya. Pencapaian suatu tujuan tidaklah mudah karena setiap perjuangan dalam pencapaian tujuan terselip persoalan-persoalan yang membuat tokoh utama tidak mudah mencapai tujuanya. Persoalan-persoalan yang dihadapi Sabungan ternyata tidak sesuai untuk mendapatkan perkerjaan dengan penghasilan yang besar dan mengambil tindakan untuk mencari jalan pintas dan terlibat masalah dengan satu kelompok penjahat pimpinan Big Pane dan Sabungan mendapatkan luka dibagian tubuhnya dan harus diantar ke rumah sakit. 
Berikutnya dalam film Mutiara Dari Toba dengan tokoh utamnya adalah Mariana. Pada awal cerita Mariana adalah seseoran gadis yang berasal dari Desa Tomok Kabupaten Samosir. Mariana berkeinginan untuk memajukan kembali wisata Danau Toba yang ada di Kabupaten Samosir yang mulai menurun oleh peminat wisatawan. Film Mutiara dari Toba sendiri bergendre drama, yang pada dasarnya drama berarti pencerminan dalam kehidupan manusia di masyarakat. Menurut Mark drama yang baik biasanya memiliki konflik yang selalu terkait dengan tema alur. Tema terbangun melalui alur yang kuat dan alur tersebut dapat menarik perhatian karena tersusun dengan jalinan konflik-konflik yang matang dan terarah serta tersebar secara merata dalam setiap alur tersebut (Mark, 1985:85). Ketika Mariana menolong dua gadis kota asal Medan yang sedang melakukan tugas akhir kuliah, yaitu Katrin dan Amel. Saat melakukan tugas akhir itu, kedua mahasiswi ini kehilangan tas, dimana Katrin, wanita kota tersebut mulai jatuh cinta dengan seorang dokter setempat bernama James.

James sendiri adalah dokter yang kembali ke kampung halamannya untuk mengabdi. Tetapi, cinta dua muda-mudi ini harus terhalang. Karena, Mariana juga menyukai sang dokter. Dua sahabat itu mencintai orang yang sama. Dengan terpaksa, Katrin harus menolak cinta James. Selain itu, ada juga pengusaha property yang ingin membeli sebuah desa. Tujuan yang ingin dicapai oleh tokoh utama dalam film Mutiara Dari Toba yaitu Mariana mengajak sahabatnya untuk membangkitkan kembali wisata Danau Toba agar kembalinya minat para wisatawan untuk berkunjung ke Danau Toba serta mempromosikan Budaya Batak Toba yang ada di Samosir. Pencapaian suatu tujuan tidaklah mudah karena setiap usaha dalam pencapaian tujuan terselip persoalan-persoalan yang membuat tokoh utama tidak mudah mencapai tujuanya. Persoalan-persoalan yang dihadapi Mariana tidak semudah itu karena salah satunya untuk memajukan wisata Danau Toba, Mariana juga ingin mencintai James sebagai suaminya tetapi James memilih mencintai Katrin. Pada akhir plot dalam film Mutiara Dari Toba Mariana tidak mendapatkan lelaki yang ia cintai untuk mempertahakan cintanya dan belum bisa memajukan wisata Danau Toba dalam promosi budaya Batak Toba.

\section{B. Unsur Sinematik}

Unsur naratif dapat dikatakan sebagai pembenuk cerita, sedangkan unsur sinematik adalah semua aspek teknis dalam produksi sebuah film. Dengan kata lain, unsur naratif diibaratkan sebuah nyawa sedangkan unsure sinematik adalah tubuh atau fisiknya. Unsur Sinematik sama pentingnya dengan unsur naratif, karena unsur sinematik inilah yang membuat sebuah cerita menjadi sebuah karya audio visual berupa film. Unsur sinematik meliputi :

\section{Mise-en-scene}

Mise-en-scene merupakan segala hal yang terletak didepan kamera yang akan diambil gambarnya dalam sebuah produksi film. Mise-en-scene berasal dari bahasa Perancis yang memiliki arti "putting in the scene". Mise-en-scene dapat mudah dikenali karena seluruh gambar yang tampil dilayar kaca film adalah bagian dari unsur ini. Mise-en-scene terdiri dari empat aspek utama, yaitu :

a. Setting (Latar)

Setting merupakan seluruh latar bersama segala propertinya, dalam hal ini adalah semua benda tidak bergerak seperti perabot, kursi, pintu, dan lain sebagainya. Setting sebuah film umumnya dibuat senyata mungkin dengan konteks ceritanya. Pada Setting akan membahas film-film yang berlatar budaya Batak Toba terdiri dari film Sinamot, Toba Dreams, Mursala, Anak Sasada dan Mutiara Dari Toba. Menurut Pratista menyatakan bahwa :

Setting adalah salah satu elemen utama yang sangat mendukung aspek naratif sebuah film. Tanpa setting,cerita film tidak mungkin dapat berjalan (Pratista, 2017: 101).

Fungsi utama setting sebagai petunjuk ruang dan waktu serta juga berperan memberikan informasi yang kuat untuk mendukung cerita filmnya. Selain berfungsi sebagai latar cerita, setting juga mampu membangun mood sesuai dengan tuntutan cerita. Pada film Sinamot mengambil setting cerita pada dua lokasi yaitu di Medan dan Serdang Bedagai. Hal ini tentu disesuaikan pula dengan isi cerita pada film Sinamot yang mengemukakan adat Batak dengan menunjukkan tokoh pemuda Batak mengenai perjuangan untuk memenuhi Sinamot. Perbedaan antara kedua kota tersebut seolah sutradara ingin memberikan penjelasan kepada penonton mengenai perspektif yang ada pada masyarakat Batak Khususnya Batak Toba dipedesaan dengan masyarakat Batak Toba yang sudah 
berada dikota. Hal tersebut terlihat pada isi cerita film Sinamot antara tokoh Niko dengan tokoh Maya. Tetapi tidak hanya itu, beberapa setting di ambil di daerah Serdang Bedagai dan Medan dengan mengeksplor daerah-daerah wisata yang menonjol seperti Pantai Mangrove, Pajak Setia Budi, Gedung Royal Sumatera dan sebagainya. Salah satu bentuk lokasi shooting film Sinamot terdapat pada gambar sebagai berikut :

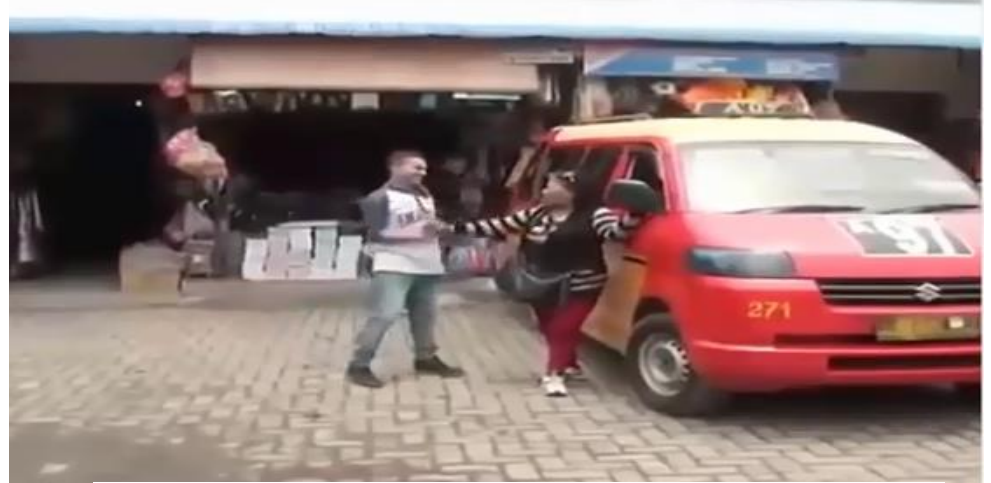

Gambar 2. Niko dan Inong bertemu di Pajak Setia Budi Medan (Sumber.Suryanto. Capture film Sinamot.2018)

Pada gambar 2 seolah sutradara ingin menunjukkan tempat perbelanjaan atau pajak dimana Niko bekerja sekaligus sebagai supir angkot serta penjelasan kepada penonton bahwasannya sutradara ingin mempromosikan pusat perbelanjaan yang salah satunya berada di Kota Medan.

Kemudian pada Film Toba Dreams mengambil setting pada dua lokasi yaitu Balige dan Jakarta. Hal ini tentu disesuaikan pula dengan isi cerita pada film Toba Dreams yang berkeinginan Sersan TB ayahnya Ronggur beserta keluarganya untuk hidup bahagia dikampung halamannya di tanah batak dengan uang pensiunan militer ketika berada di Jakarta. Adapun setting yang terdapat dalam film Toba Dream yang dapat dilihat pada gambar sebagai berikut :

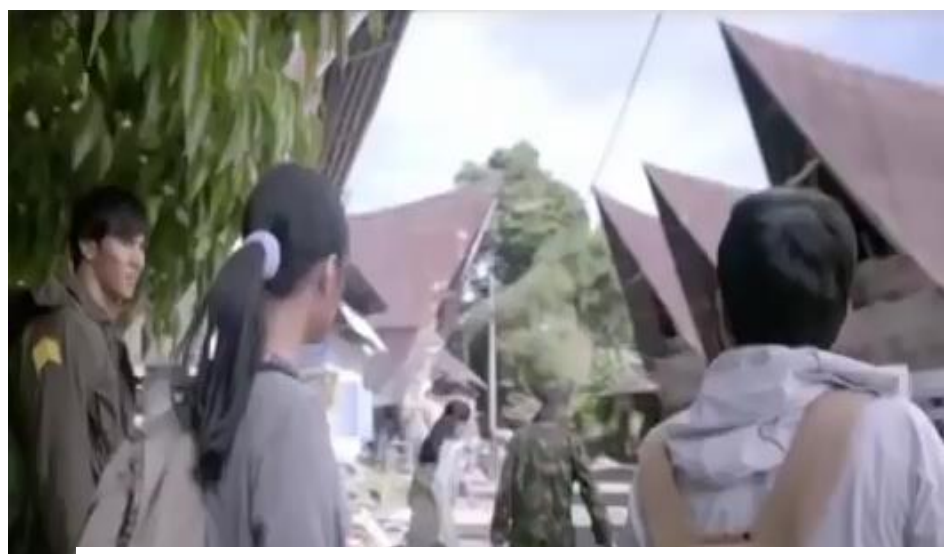

Gambar 3. Sersan TB beserta keluarga kembali ke kampong halamannya

(Sumber.Suryanto. Capture film Toba Dreams.2018)

Pada gambar 3 menyatakan bahwa sutradara ingin memperkenalkan salah satu rumah adat Batak Toba sekaligus mempromosikan kepada penonton sebagai daya tarik yang menjadi salah satu tempat wisata, perbedaan antara kedua kota tersebut seolah sutradara ingin memberikan penjelasan kepada penonton mengenai perspektif yang ada pada masyarakat Batak Khususnya Batak Toba dipedesaan. Hal tersebut terlihat pada isi cerita film Toba Dreamsantara tokoh Sersan TB dengan keluarganya dan tokoh Andini. Tetapi tidak hanya itu, beberapa setting kebanyakan di ambil di daerah Balige dengan mengeksplor daerah-daerah wisata yang menonjol di Balige seperti Danau Toba, Museum TB Silalahi, Gereja HKBP Balige, Pelabuhan Kapal Pakkudian, Rumah adat Batak didaerah Desa Siambat Dalan, Pulau Sibandang, Hotel Tiara Bunga dan sebagainya.

Berikutnya tidak kalah menarik pada film Mursala yang mengambil setting pada dua lokasi yaitu Tapanuli Tengah dan Jakarta. Hal ini tentu disesuaikan pula dengan isi cerita pada film 
Mursala yang mengemukakakn adat Batak Toba dengan menunjukkan tokoh pemuda Batak desa yang merantau ke kota metropolitan seperti Jakarta. Perbedaan antara kedua kota tersebut seolah sutradara ingin memberikan penjelasan kepada penonton mengenai perspektif yang ada pada masyarakat Batak Khususnya Batak Toba dipedesaan dengan masyarakat Batak Toba yang sudah berada di kota. Hal tersebut terlihat pada isi cerita film Mursalaantara tokoh Anggiat dengan keluarganya dan tokoh Clarisa. Tetapi tidak hanya itu, beberapa setting kebanyakan di ambil di daerah Tapanuli Tengah dengan mengeksplor daerah-daerah wisata yang menonjol di daerah Tapanuli Tengah seperti Pantai Binasih, Pulau Mursala (yang dijadikan nama film Mursala), Air Terjun Mursala, Pulau Puteri, Pulau Pandan, Sibolga, Makam Papan Tinggi dan sebagainya. Terdapat tempat setting pada film Mursala dilihat pada gambar sebagai berikut :

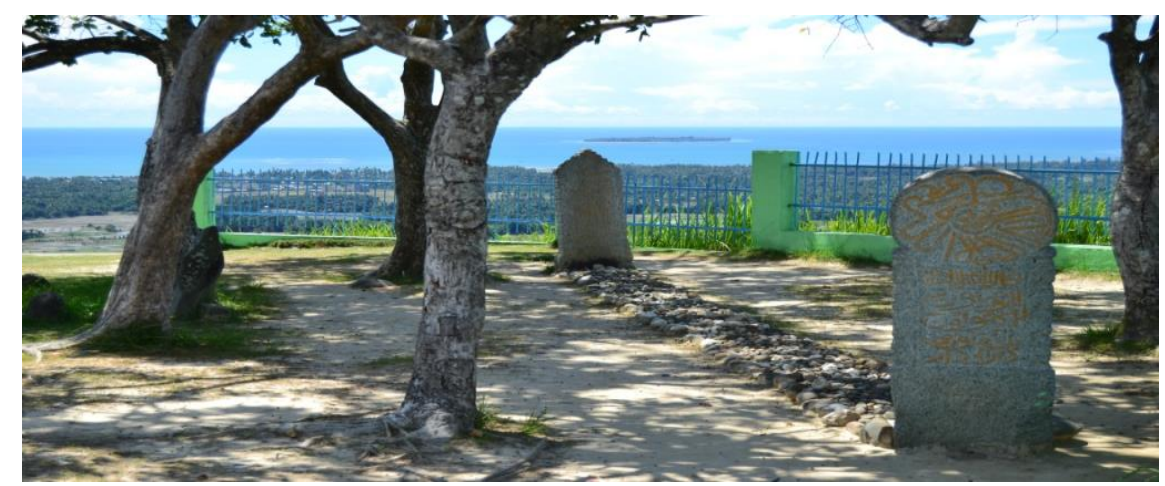

Gambar 4. Makam Papan Tinggi

(Sumber.Suryanto. Capture film Mursala.2018)

Berikutnya pada film Anak Sasada mengambil setting cerita pada dua lokasi yaitu Balige dengan latar belakang kapal "paronan" (pedagang) dari Bakkara dan Medan. Hal ini tentu disesuaikan pula dengan isi cerita pada film Anak Sasada yang mengemukakakn adat Batak Toba dengan menunjukkan tokoh pemuda Batak desa yang merantau ke kota metropolitan seperti Medan. Perbedaan antara kedua kota tersebut seolah sutradara ingin memberikan penjelasan kepada penonton mengenai perspektif yang ada pada masyarakat Batak Khususnya Batak Toba dipedesaan dengan masyarakat Batak Toba yang sudah berada di kota. Hal tersebut terlihat pada isi cerita film Anak Sasadaantara tokoh Sabungan dengan keluarganya. Tetapi tidak hanya itu, beberapa setting kebanyakan di ambil di kota Medan dengan mengeksplor daerah-daerah wisata yang menonjol di Kota Medan seperti Istana Maimun, Mesjid Raya Medan, dansebagainya. Adapaun salah satu tempat setting dalam film Anak Sasada terlihat pada gambar sebagai berikut :

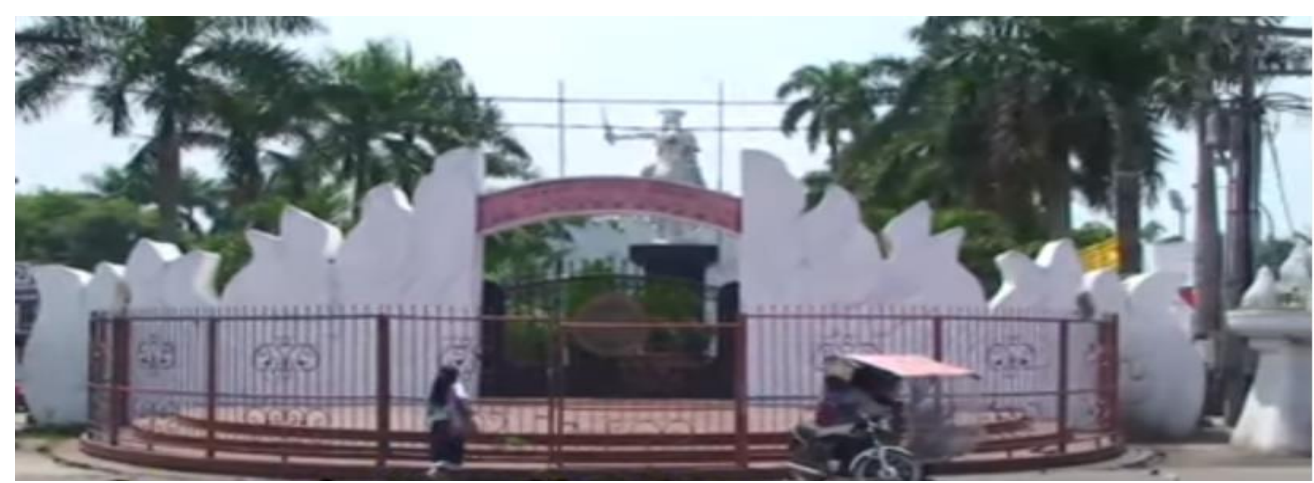

Gambar 5. Monumen Sisingamangaraja XII

(Sumber.Suryanto. Capture film Anak Sasada.2018)

Selanjutnya film Mutiara Dari Toba yang mengambil setting cerita pada dua lokasi yaitu Samosir dan Medan. Hal ini tentu disesuaikan pula dengan isi cerita pada film Mutiara Dari Toba yang mengisahkan dua gadis dari Medan yang berkunjung ke Danau Toba untuk melakukan penelitian tugas dari kuliah. Sutradara ingin memberikan penjelasan kepada penonton mengenai 
perspektif yang ada pada masyarakat Batak Khususnya Batak Toba yang kurang untuk memperhatikan wisata budaya Batak Toba serta menggambarkan usaha perjuangan gadis asal Samosir untuk mengembalikan kejayaan terutama dalam bidang budaya Batak Toba dan wisata Danau Toba. Hal tersebut terlihat pada isi cerita film Mutiara Dari Tobaantara tokoh Marian dengan tokoh Katrin, Amel dan James. Tetapi tidak hanya itu, beberapa setting kebanyakan di ambil di daerah Samosir dengan mengeksplor daerah-daerah wisata yang menonjol di daerah Samosir seperti Puskesmas daerah Tuk-tuk, Batu Kursi Raja Siallagan, Danau Toba, toko ukiran kerajinan Batak Toba, Pembuatan kain Ulos, Patung sigale-gale, Pesenggrahan Bung Karno dan sebagainya. Adapaun salah satu tempat setting dalam film Anak Sasada terlihat pada gambar sebagai berikut :

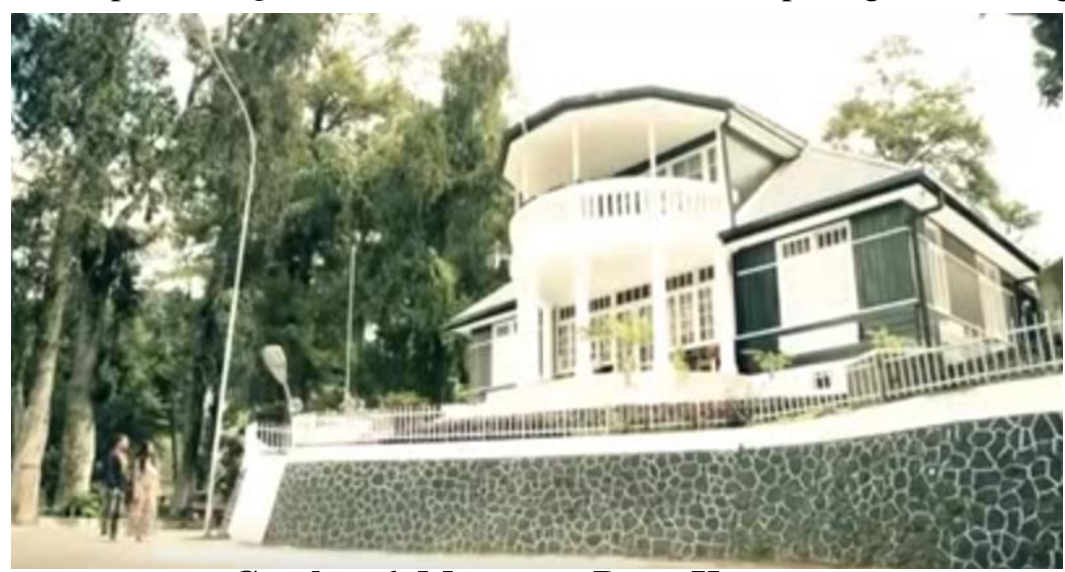

Gambar 6. Monumen Bung Karno

(Sumber.Suryanto. Capture film Mutiara Dari Toba.2018)

b. Kostum dan Tata Rias Wajah (make-up)

Kostum dan tat arias memiliki dua fungsi yaitu untuk menunjukkan usia dan untuk menggambarkan ajah non manusia. Tata rias wajah biasanya digunakan karena wajah pemain tidak seperti yang diharapkan seperti dalam cerita filmnya.

Kostum dan tata rias juga sama pentingnya dari setting karena hal ini saling berkaitan satu sama lain. Kostum yang digunakan mampu memperlihatkan karakter pemainnya, serta memperkuat kesa pemeran atau pemain. Sedengkan tata rias biasanya digunakan langsung kepada permukaan kulit seorang aktor baik untuk tujuan artistik atau komestik. Menurut Pratista menyatakan bahwa :

Kostum dan tat arias adalah segala hal yang dikenakan pemain bersama seluruh aksesorisnya. Aksesori kostum termasuk diantaranya, topi, perhiasan, jam tangan, baju, celana, sepatu dan sebagainya (Pratista, 2017: 104).

Film Sinamot bercerita menganai budaya Batak khususnya Batak Toba, tentu kostum dan rias yang digunakan disesuaikan dengan tema pada film tersebut yaitu adat Batak khususnya Batak Toba yang berada di perkotaan. Tetapi pada film Sinamot tidak terdapat kostum adat Batak Toba disebabkan lebih memfokuskan pakaian popular. Adapun kostum dan rias yang terdapat pada gambar sebagai berikut :

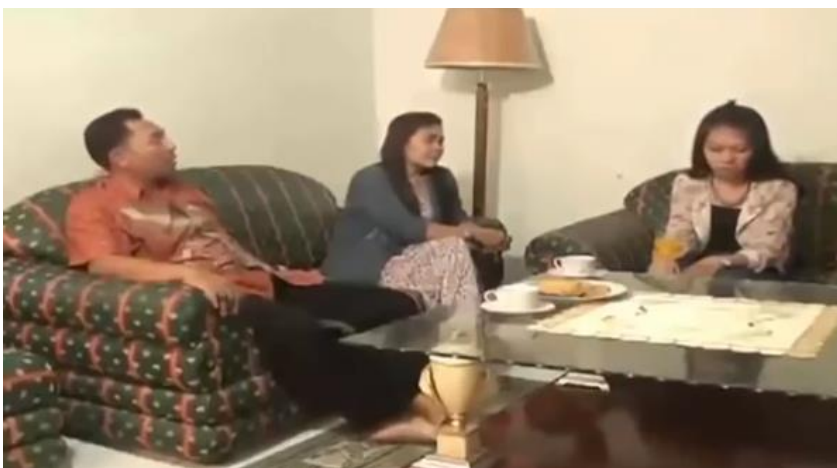

Gambar 7. Keluarga Maya menggunakan kostum populer (Sumber.Suryanto. Capture film Sinamot.2018) 
Pada gambar 7 sutradara ingin memperlihatkan adanya perubahan dari segi kostum dan rias yang digunakan, dimana terlihat pada gambar tersebut menunjukan bahwa terdapat kostum popoler yakni tidak terdapat kostum dan rias yang menggambarkan adat Batak Toba.

Sedangkan film Toba Dreams bercerita mengenai budaya Batak khususnya Batak Toba, tentu kostum dan rias yang digunakan disesuaikan dengan tema pada film tersebut yaitu ada Batak Toba. Kostum dan tata rias yang paling menonjol pada film Toba Dreams terlihat pada sequence tersebut para pemain menggunakan kostum adat Batak lengkap dengan tarian dan music pengeringnya. Berikut capture scene 95 yang memperlihatkan kostum dan tata rias pada film tersebut :

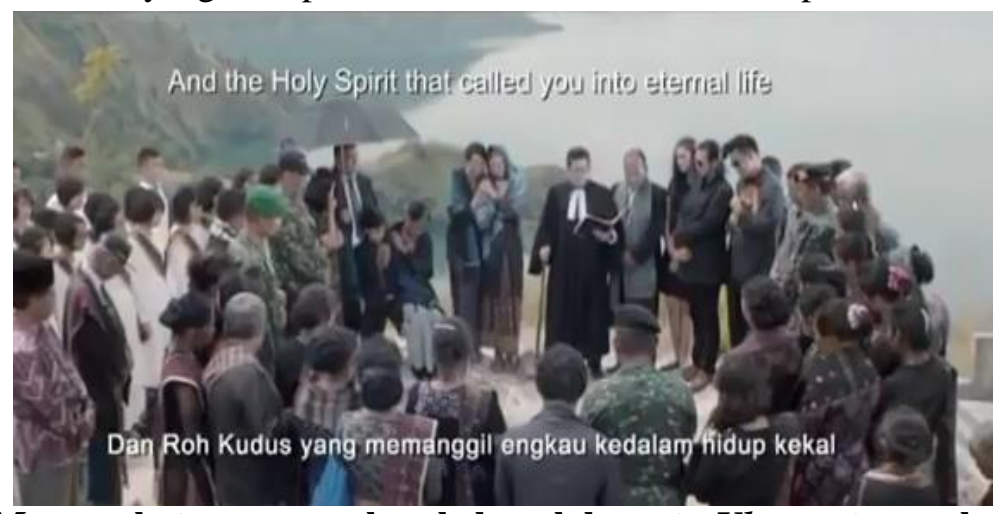

Gambar 8. Masyarakat menggunakan kebayak beserta Ulos saat pemakaman Ronggur (Sumber. Suryanto. Capture film Toba Dreams.2018)

Berikutnya film Mursala bercerita mengenai budaya Batak khususnya Batak Toba, tentu kostum dan rias yang digunakan disesuaikan dengan tema pada film tersebut yaitu ada Batak Toba. Kostum dan tata rias yang paling menonjol pada film Mursala terlihat pada sequence II. Squence tersebut para pemain menggunakan kostum adat Batak lengkap dengan tarian dan musik pengeringnya. Berikut capture scene 20 yang memperlihatkan kostum dan tata rias pada film tersebut :

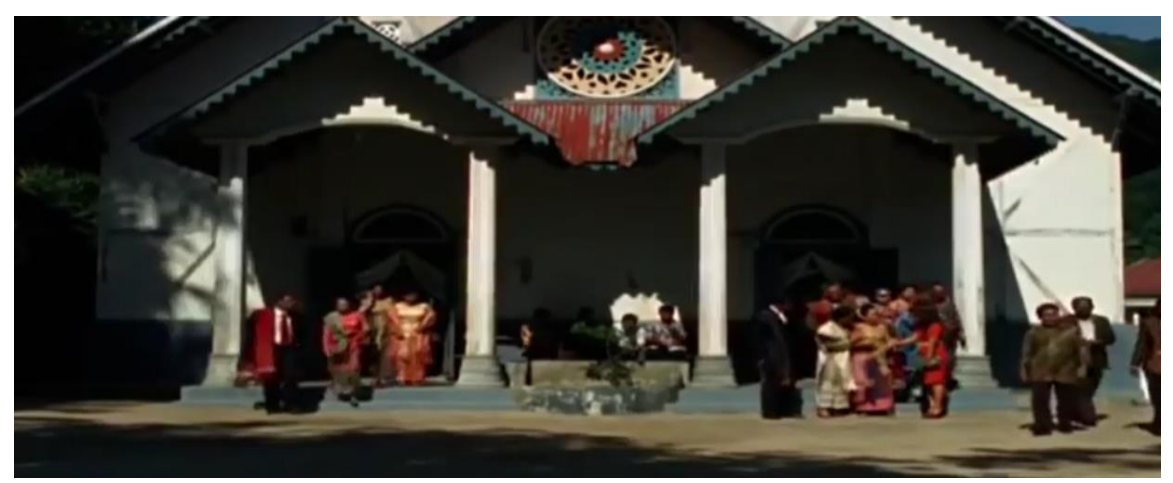

Gambar 9. Anggiat dan Keluarga menggunakan kebayak dan ulos di depan Gereja (Sumber. Suryanto. Capture film Mursala.2018)

Kemudian yang menarik lagi mengenai kostum dan tata rias yang ditampilakn dalam film Anak Sasada yang bercerita mengenai budaya Batak khususnya Batak Toba yang ada didaerah Balige, tentu kostum dan rias yang digunakan disesuaikan dengan tema pada film tersebut yaitu ada Batak Toba. Kostum dan tata rias yang paling terlihat pada film Anak Sasada pada sequence. Dimana squence tersebut para pemain menggunakan kostum adat Batak disebuah perkebunan dipedesaan yang menggunakan sarung diikat dikepala. Berikut capture scene 2 yang memperlihatkan kostum dan tata rias pada film tersebut : 


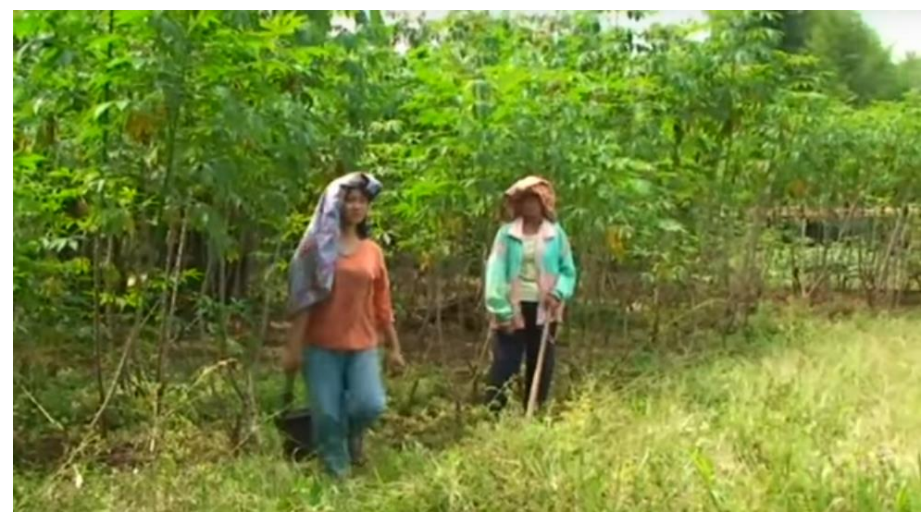

\section{Gambar 10. Adik dan Ibu Sabungan menggunakan kain tudung dikepala}

(Sumber. Suryanto. Capture film Anak Sasada.2018)

Kostum dan tata rias selanjutnya yang terakhir dalam film Mutiara Dari Toba yang bercerita bercerita mengenai budaya Batak khususnya Batak Toba, tentu kostum dan rias yang digunakan disesuaikan dengan tema pada film tersebut yaitu ada Batak Toba. Kostum dan tata rias yang paling menonjol pada film Mutiara Dari Toba terlihat pada sequence tersebut para pemain menggunakan kostum adat Batak lengkap dengan tarian dan musik pengeringnya. Akan tetapi, terlihat berbeda dengan pakaian yang digunakan Marian dan James yang berketurunan Batak dan para sahabatnya yang berasal dari Medan. Hal ini tersebut menunjukkan bahwa budaya Mariana dan James telah bercampur dengan budaya perkotaan. Berikut capture scene 101 yang memperlihatkan kostum dan tat arias pada film tersebut :

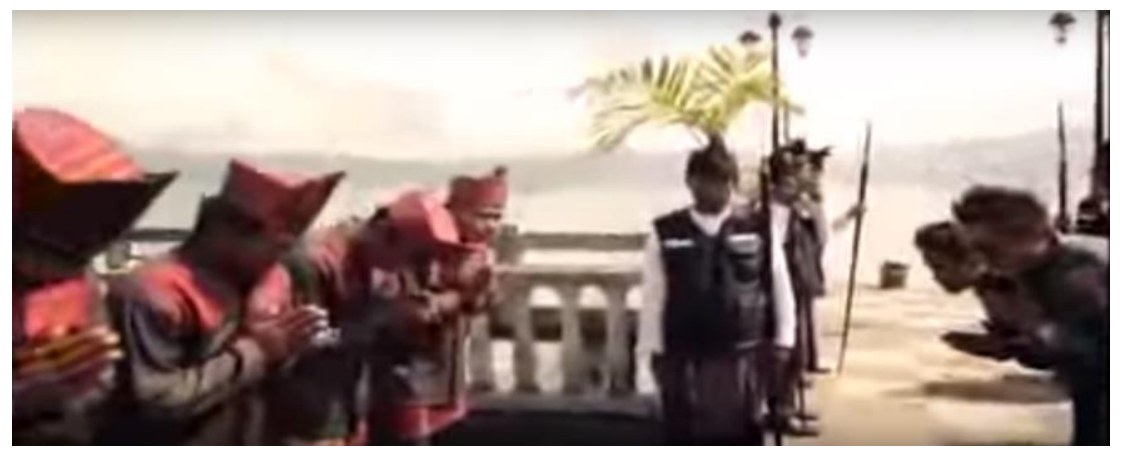

Gambar 11. para penduduk menggunakan baju dan ulos di depan Sanggar Tari (Sumber. Suryanto. Capture film Mursala.2018)

\section{c. Pencahayaan}

Seluruh gambar yang ada didalam film bisa dikatakan merupakan hasil manipulasi cahaya. Cahaya membentuk sebuah benda serta dimensi ruang. Tata cahaya dalam film secara umum dapat dikelompokkan menjadi empat unsur yaitu kualitas, arah, sumber serta warna cahaya. Keempat unsur ini sangat mempengaruhi tata cahaya dalam membentuk suasana serta mood sebuah film.

Pencahayaan merupakan hal yang cukup penting dalam sebuah karya seni media rekam. Beberapa program TV dan film seringkali menyajikan tayangan yang dikaitkan dengan gambar penuh bayangan dengan dominasi bagian gelap dan menyajikan tayangan yang memberikan suspense dengan menggunakann low key lighting.

Low key lighting merupakan suatu teknik tata cahaya yang menciptakan batasan yang tegas antara area gelap dan terang. Teknik ini lebih mengutamakan unsur bayangan yang tegas dalam mise-en-scene. Key lightyang digunakan biasanya berintensitas tinggi dan fill light biasanya berintensitas lebih rendah atau bahkan tidak digunakan sama sekali. Low key lighting memiliki area gelap dan sedikit cahaya dan sering digunakam dalam film misteri, thriller, dan film noir (Pratista 2008, 79). 
Teknik pencahayaan dalam film Sinamot, Toba Dreams, Mursala, Anak Sasada dan Mutiara dari Toba kebanyakan menampilkan setting dengan konsep eksterior pantai-pantai dan Danau Toba di daerah Samosir,Balige, dan Medan serta dilakukan pada siang hari sehingga cahaya yang digunakan adalahh cahaya alami yaitu matahari sebagai key lightnya. Matahari dapat menimbulkan bayangan hitam, maka dari itu reflector biasanya digunakan untuk membunuh bayangan yang terlalu hitam.

\section{d. Pemain dan Pergerakannya}

Aspek yang terpenting dalam mise-en-scene, seorang sineas dapat mengontrol pemain dan pergerakannya, seperti yang telah diketahui bahwa pemain merupakan orang yang memainkan peran tertentu dalam suatu aksi panggung, acara televisi, atau film. Adapun pelaku cerit dapat dikelompokkan menjadi beberapa jenis sesuai tuntutan dan fungsinya dalam sebuah film. Salah satu kunci utama untuk menentukan keberhasilan sebuah film adalah performa seorang pemain (acting).

Karakter atau aktor yang dibawakan oleh Rimbun Nadeak dalam film Sinamot dan selaku tokoh utama dalam film telah menguatkan isi cerita, dengan berlogat Batak mampu merealisasikan tokoh Niko sebagai pemuda Batak. Begitu juga dengan karakter-karakter tokoh lain, namun ada sedikit kelemahan pada karakter tokoh Yanti yang diperankan oleh Amalia Siregar. Amalia Siregar berperan sebagai adik angkat Niko tetapi Amalia mencintai Niko. Pada scene 12 dimenit tujuh belas Yanti (Amalia Siregar) mengungkapkan cintanya kepada Niko. Namun, Amalia Siregar masih terlihat kaku dan kurang mendapatkan chemestry dalam mengutarakan cintanya. Selain Amalia Siregar, karakter Mamak Nong yang diperankan oleh Nong Zuraidah juga terlihat kaku dan kurang menjiwai karakter Mamak Nong. Karakter yang bagus dan menonjol mampu diperankan dengan terlihat baik dari karakter Maya (Frisna Mariana Panjaitan) dan Niko (Rimbun Nadeak) dengan cara berbicara yang baik layaknya orang Batak.

Kemudian karakter yang ada didalam film Toba Dreams yang dibawakan oleh Vino G Bastian sebagai Ronggur dan selaku tokoh utama dalam film tersebut telah menguatkan isi cerita, dengan berlogat Batak dan sedikit berwatak keras Vino mampu menguasai tokoh Ronggur sebagai pemuda Batak meskipun pada dialog Vino masih terlihat sedikit kaku. Begitu juga dengan karakter-karakter tokoh lain, namun ada sedikit kelemahan pada karakter tokoh Andini yang diperankan oleh Marsha Timothy. Marsha Timothy berperan sebagai kekasih Ronggur yang berasal dari Kota Jakarta. Pada scene 59 di menit empat puluh tiga Andini (Marsha Timothy) mengutarakan maaf dan sangat mencintai Ronggur sebagai kekasihnya. Namun, acting Marsha masih terlihat kaku dan terlihat kurang mendapatkan chemistry. Selain Marsha, karakter Samurung yang diperankan oleh Haykal Kamil juga terlihat kurang menjiwai dan terlihat kakau dalam berlogat sebagai orang Batak. Karakter yang menonjol mampu diperankan dengan terlihat baik dari karakter Sersan Tebe (Mathias Muchus) dan Opung Boru (Jajang C Noer) dengan cara berbicara yang aik layaknya orang Batak.

Berikutnya karakter yang dibawakan dalam film Mursala oleh Rio Dewanto sebagai Anggiat Simbolon dan selaku tokoh utama telah memperjelas isi cerita, dengan berlogat Batak dan sedikit lantanng Rio mampu merealisasikan tokoh Anggiat sebagai pemuda Batak meskipun pada dialog Rio masih terlihat sedikit terbata-bata. Begitu juga dengan karakter tokoh lain, namun ada sedikit kelemahan ada karakter tokoh Clarisa Saragih yang diperankan oleh Anna Sinaga. Anna Sinaga berperan sebagai kekasih Anggiat yang berasal dari suku Batak tetapi menetap di Kota Jakarta. Pada scene 10 dimenit Sembilan Claris (Anna Sinaga) memperkenalkan karakternya sebagai kekasih Anggiat. Namun, acting Anna Sinaga masih terlihat kaku dan terlihat kurang mendapatkan chemistry layaknya pasangan kekasih. Selain Anna Sinaga, karakter Inang yang diperanan oleh Dra. Reiny ch Situmeang juga terlihat kaku dan kuranng menjiwai karakter Inang. Karakter yang menonjol yang mampu diperankan dengan baik terlihat karakter Uli (Titi Rajo Bintang) dan bapak Uda (Tio Pakusadewo) dengan cara berbicara yang baik layanknya orang Batak.

Hal ini juga terdapat pada film Anak Sasada dimana dalam film ini karakter diwajibkan berbicara bahasa Batak tanpa adanya bahasa Indonesia. Karakter yang dibawakan oleh Ebenezer sebagai Sabungan dan selaku tokoh utama telah mampu berjalan dengan baik pada isi cerita, dengan berlogat Batak yang mampu merealisasikan tokoh Sabungan sebagai pemuda Batak meskipun pada dialog Ebenezer terlihat kurang menjiwai. Begitu juga dengan karakter-karakter tokoh lain, namun ada sedikit kelemahan pada karakter tokoh Rotua yang diperankan oleh Widya 
Minar Christine. Widya Minar Christine sebagai adik dari Sabungan yang sangat menyayangi dan menghormati keluarganya. Pada scene 11 di menit empat belas Rotua (Widya Minar Christine) sangat sedih dan menahan abangnya Sabungan untuk tidak pergi meninggalkan rumahnya. Namun, acting Widya Minar Christine masih terlihat kaku dan terlihat kurang mendapatkan chemistry sedihnya. Selain Widya Minar Christine, karakter yang meonjol yang mampu diperankan dengan baik terlihat dari karakter Inong (Ojax Manalu) dengan cara berbicara dan menjiwai karakter dan baik layaknya orang Batak.

Film yang selanjutnya adalah film Mutiara dari Toba yang dibawakan oleh Frisna Mariana Panjaitan sebagai Mariana dan selaku tokoh utama telah menguatkan isi cerita, dengan berlogat Batak dan sediki lembut Frisna mampu berperan baik sebagai tokoh Mariana sebagai gadis Batak meskipun pada dialog Frisna terlihat sedikit kaku. Begitu juga dengan karakter-karakter tokoh lain, namun ada sedikit kelemahan pada karakter tokoh James yang diperankan oleh Rimbun Nadeak. Rimbun Nadeak berperan sebagai Dokter disalah satu desa Samosir dan laki-laki yang dicintai oleh Mariana. Pada scene 94 di delapan puluh James (Rimbun Nadeak) menceritakan bahwsannya James tidak mencintai Mariana dan ingin mencintanya Katrin. Namun, acting Rimbun Nadeak masih terlihat kurang menjiwai. Selain Rimbun Nadeak, Karakter Amel yang diperankan oleh Amalia Siregar juga terlihat kaku sama halnya dengan karakter Cinta yang kurang menjiwai. Karakter yang sangat terlihat bagus yang mampu diperankan dengan bagus terlihat dari karakter Katrin (Anggi Rahma Ulfha) dengan cara berbicara dan acting yang baik.

\section{Sinematografi}

Sinematografi sebagai ilmu terapan merupakan bidang ilmuyang membahas tentang teknik menangkap gambar dan menggabung-gabungkan gambar tersebut sehingga menjadi rangkaian gambar yang dapat menyampaikan ide cerita.Sinematografi memiliki objek yang sama dengan fotografi yakni menangkap pantulan cahaya yang mengenai benda. Karena objeknya sama maka peralatannyapun mirip. Perbedaannya, peralatan fotografi menangkap gambar tunggal, sedangkan sinematografi menangkap rangkaian gambar. Penyampaian ide pada fotografi memanfaatkan gambar tunggal, sedangkan pada sinematografi memanfaatkan rangkaian gambar. Jadi sinematografi adalah gabungan antara fotografi dengan teknik perangkaian gambar atau dalam sinematografi disebut montase (Pratista, 2008:78).

Teknik sinematografi merupakan sebuah cara dalam pembuatan film yang meliputi angel gambar, moving gambar, komposisi gambar, dan tata lighting. Semua unsur yang terdapat dalam teknik sinematografi sangat dibutuhkan untuk membuat sebuah karya seni film. Teknik tersebut terdapat pula pad film Sinamot, Toba Dreams, Mursala, Anak Sasada, dan Mutiara dari Toba yang membentuk estetika dalam seni visual (film) yang memiliki makna. Salah satu capture gambar yang menunjukkan estetik dari film Sinamot terlihat pada saat gambar berikut :

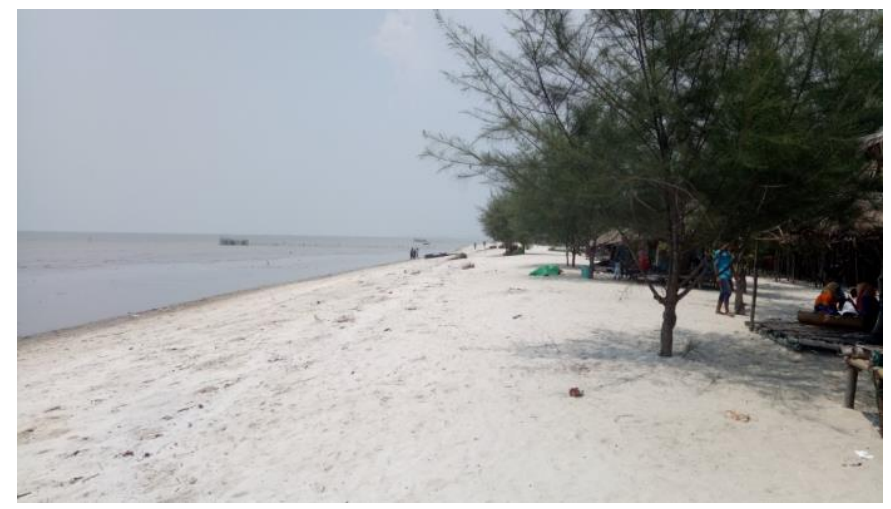

\section{Gambar 12. Pemandangan Pantai di Serdang Bedagai}

(Sumber.Suryanto. Capture film Sinamot.2018)

Film ini ingin memperlihatkan keindahan tempat wisata pantai yang dikelilingi dengan tumbuhan hutan bakau atau disebut dengan mangrove yang ada di daerah Serdang Bedagai. Selain untuk memperlihatkan keindahaan secara estetika, film ini juga menunjukkan sebuah identitas tempat wisata agar penonton dapat mengetahui tempat wisata tersebut. 
Begitu juga dengan film Toba Dreams yang memperlihatakan rumah adat Batak Toba. Adapun gambar yang terdapat sebagai berikut :

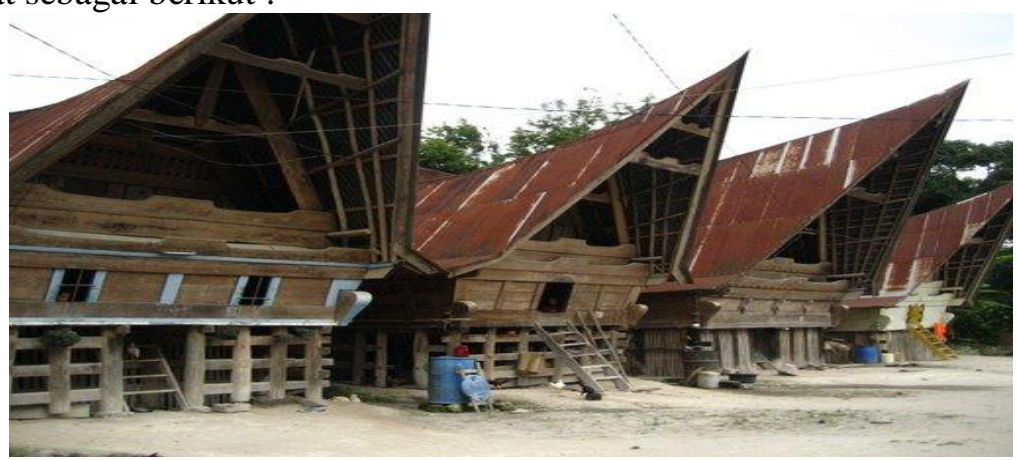

Gambar 13. Rumah adat Batak Toba

(Sumber.Suryanto. Capture film Sinamot.2018)

Telihat sutradara ingin memperlihatkan sebuah rumah adat khas Batak Toba sebagai simbol dan identitas masyarakat Batak Toba tersebut. Selain untuk memperlihatkan sebagai identitas rumah adat Batak Toba, film ini menggambarkan sebuah promosi dan memperkenalkan kepada penonton bentuk dan arsitektur pembangunan rumah khas adat Batak Toba dimana bentuk atapnya yang melengkung dan pada ujung atap sebelah depan kadang-kadang dilekatkan tanduk kerbau, sehingga rumah adat itu menyerupai kerbau dan sebagainya.

Kemudian yang menarik pada film Mursala yang menampilkan pantai-pantai dan air terjun di Tapanuli Tengah. Adapun gambar yang terdapat sebagai berikut :

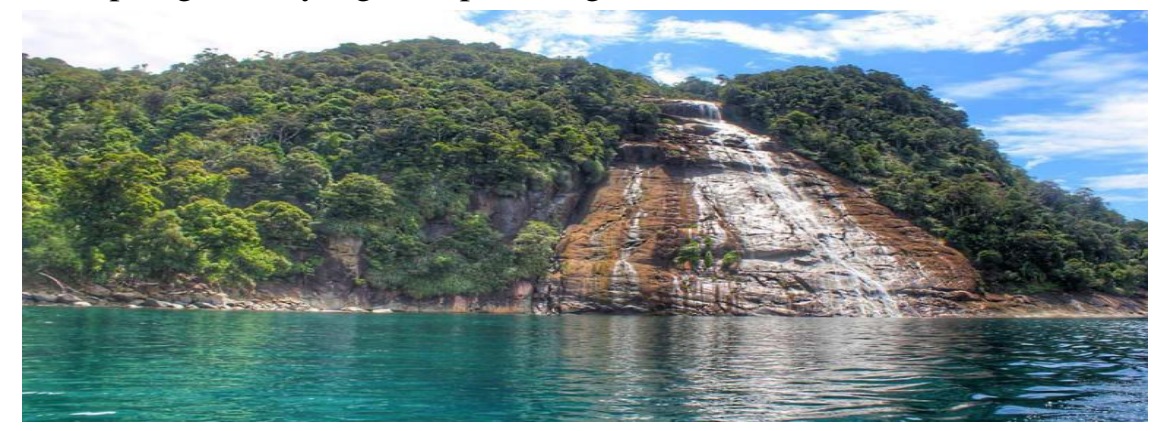

Gambar 14. Pemandangan Air Terjun Mursala Tapanuli Tengah (Sumber.Suryanto. Capture film Mursala.2018)

Sutradara ingin memperlihatkan sebuah tempat wisata yang menjadi estetika dalam film untuk menggambarkan tempat wisata atau pemandangan-pemdandangan yang menjadi simbol atau identitas tersebut pada masyarakat Batak Toba. Air terjun ini disebut dengan air terjun Mursala sebagai tempat wisata yang ada di Tapanuli Tengah yang sesuai dengan judul yang terdapat dalam film yaitu film Mursala.

Selanjutnya pada film Anak Sasada yang juga memperlihatkan pulau-pulau dan pemandangan Danau Toba. Terdapat gambar yang ada pada film Anak Sasada sebagai berikut :

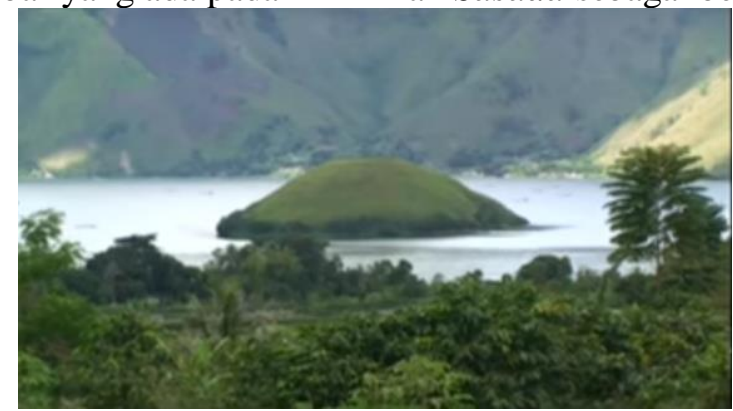

Gambar 15. Pemandangan paronan Bakkara, Balige

(Sumber.Suryanto. Capture film Sinamot.2018) 
Terdapat sebuah pulau yang terdapat di Danau Toba yang diperlihatkan dalam film Anak Sasada yang dikenal dengan daerah paronan Bakkara. Terlihat sutradara yang ingin disampaikan melalui film untuk menjadi sebuah estitika film dan memperlihatkan sebuah pulau yang dikelilingin bukit-bukit serta Danau Toba yang menjadi identitas tempat masyarakat Batak Toba.

Terakhir pada film Mutiara dari Toba yang menampilkan wisata kota medan dan wisata Danau Toba di Samosir. Salah satu capture dalam film tersebut terlihat pada gambar sebagai berikut :

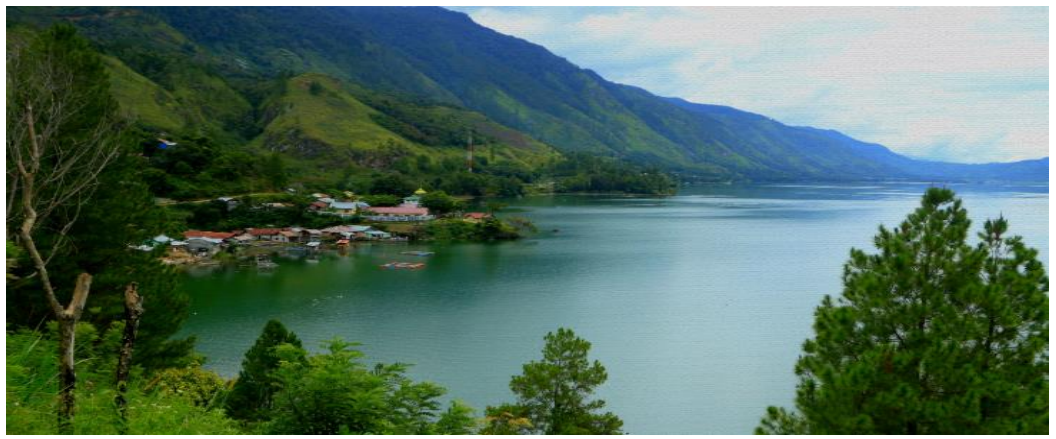

Gambar 16. Pemandangan Samosir

(Sumber.Suryanto. Capture film Mutiara Dari Toba.2018)

Hal ini seakan sutradara ingin memberikan sebuah ikonitas dari film tesebut dengan pesona yang indah dari sebuah wisata Danau Toba yang dikelilingi dengan bukit-bukit dan Danau Toba tersebut yang menjadi estetika film itu sendiri agar penonton dapat melihat suasana keindahan dan mempromosikan wisata tersebut agar penonton tertarik untuk mengunjunginya.

\section{Editing}

Pada tahap produksi editing adalah proses pemilihan serta penyambungan gambar-gambar yang telah diambil. Ada banyak alasan kita melakukan pengeditan dan pendekatan editing sangat bergantung dari hasil yang kita inginkan, yang terpenting adalah ketika kita melakukan pengeditan, pertama adalah menetapkan tujuan kita melakukan editing Defenisi editing adalah proses pemilihan serta menggabungkan gambar-gambar yang telah diambil saat produksi, sementara editing pada saat pasca produksi merupakan teknik-teknik yang digunakan untuk menghubungkan setiap shotnya.

Pada tahap editing biasanya seorang editor akan menggambungkan potongan gambar ke shot sehingga gambar-gambar tersebut membentuk satu kesatuan (sekuen) dalam sebuah film. Beberapa transisi juga digunakan dalam film Sinamot, Toba Dreams, Mursala, Anak Sasada, dan Mutiara Dari Toba untuk menghubungkan satu kesatuan tersebut.

\section{Suara}

Suara merupakan seluruh suara yang keluar dari gambar (film), yang dapat dikelompokkan menjadi tiga jenis yaitu dialog, musik dan efek suara (Pratista, 2008). David Brodwell menjelaskan dalam bukunya bahwa suara atau sound yaitu :

Sound is a powerfull film technique for serval reason. For one thing, it engages a distinct mode.

Suara adalah teknik film yang sangat kuat karena beberapa alas an. Untuk satu hal, ini melibatkan mode rasa yang berbeda (Brodwell \& Thompson: 2004: 348).

Melalui suara pesan yang akan disampaikan dalam film kepada penonton menjadi lebih mudah. Penonton dapat menangkap pesan dengan adanya unsur suara tersebut untuk mendukung pencapaian pesan yang ingin disampaikan oleh penonton.

\section{Konsep Patrilineal Dalam film berlatar budaya Batak Toba pada film Sinamot, Toba Dreams, Mursala, Anak Sasada dan Mutiara Dari Toba.}

\section{Sistem Patrilineal}


Masyarakat batak toba menganut sistem kekeluargaan sistem patrilineal yaitu keturunan yang diambil dari ayahnya. Dilihat dari marga yang dipakai oleh orang Batak yang diambil dari marga ayahnya. Dimana jika terjadi sesuatu maka keturunan pihak ayah yang akan bertanggung jawab dalam sebuah keluarganya tersebut.

Film pada prinsipnya sangat berhubungan dengan simbolik yang berisikan tentang maknamakna melalui tanda dan penanda yang ada pada film tersebut. Menurut Sobur, film merupakan bidang kajian yang sangat relevan bagi analisis struktural atau semiotika. Film dibangun dengan tanda semata-mata, dalam film juga menggunakan tanda-tanda ikonis yaitu tanda-tanda yang menggambarkan sesuatu. Rangkaian gambar dari film menciptakan imaji dan system penandaan. Ciri gambar-gambar film merupakan persamaannya dengan realitas yang ditunjukkan. Gambar yang dinamis dalam film merupakan ikonis bagi realitas yang dinotasikannya (Sobur, 2009: 128).

Sebagaimana yang dinyatakan oleh Sobur, film Sinamot, Toba Dreams, Mursala, Anak Sasada dan Mutiara Dari Toba memiliki arti simbolis yang tidak terhitung jumlanya. Bentuk cerita pada film Sinamot, Toba Dreams, Mursala, Anak Sasada dan Mutiara Dari Toba menyimbolkan sesuatu yang konkrit dan mewakili. Untuk melihat konsep fenomena dalam kelima film tersebut maka diperlukan pemaknaan tanda pada film. Makna menurut Roland Barthes sebuah wahana tanda yang merupakan satuan cultural yang diperagakan oleh media-media tanda lain tentang relasi-relasi objek yang diacu (Roland Barthes, 1998:121).

Dalam kehidupan sosial budaya pada masyarakat, penggunaan tanda pada film tidak hanya dimaknai dengan denotasi (merujuk pada apa yang diyakini akal sehat atau orang banyak). Barthes menyebutkan bahwa denotasi sebagai signifikasi tahap pertama yaitu hubungan sebuah tanda dengan tanda yang mewakili realitasnya. Contoh pada film Sinamot yang menggambarkan sebuah sistem patrilineal pada perkawinan, dimana yang memegang kekuasaan ketentuan Sinamot yakni pihak perempuan dan ayah perempuan yang memiliki peranan penting serta bertanggung jawab atas keluarganya. Hal ini dapat dilihat pada tanda Roland Barthes sebagai berikut :

a. Tanda Roland Barthes pada film Sinamot Scene 12

Scene 12 memperlihatkan adanya sistem patrilineal dari Ayah Maya yang tidak bisa dirubah kembali keputusannya mengenai waktu dan biaya Sinamot dalam perkawinan kepada Maya. Hal itu terlihat ketika Ayah Maya memberitahukan kepada Maya untuk patuh dan menuruti perkataan dari Ayahnya. Sistem patrilienal terhadap ketetapan biaya Sinamot tersebut terlihat pada tabel 12 sebagai berikut :

Tabel 2. Ayah Maya memberitahukan kepada Maya bahwa ketetapan tidak bisa diubah kembali

\begin{tabular}{|c|c|}
\hline Siginified & Signifier \\
\hline \multirow[b]{2}{*}{$\begin{aligned} \text { Dialog : } & \text { Maya, kau anak kami satu-satunya } \\
& \text { dan kami mau kau dapat yang } \\
& \text { terbaik. }\end{aligned}$} & $\begin{array}{l}\text { Ayah Maya ketika menolak } \\
\text { permohanan Maya untuk dapat } \\
\text { memberikan keringanan waktu dan } \\
\text { biaya Sinamot tersebut }\end{array}$ \\
\hline & \\
\hline \multicolumn{2}{|c|}{ Denotative Sign } \\
\hline \multicolumn{2}{|c|}{$\begin{array}{c}\text { Ekspresi yang ditunjukkan oleh seseorang Ayah yang tidak ingin anaknya hidup } \\
\text { sengsara }\end{array}$} \\
\hline Conotative Signifier (Penanda Konotatif) & Conotative Signified (Petanda Konotatif) \\
\hline $\begin{array}{l}\text { Ungkapan keteguhan Ayah Maya yang ingin } \\
\text { mempertahankan keputusannya }\end{array}$ & $\begin{array}{l}\text { Dengan ketegasan Ayah Maya yang } \\
\text { memberikan keputusan yang tidak dapat } \\
\text { dirubah kembali walaupun anaknya } \\
\text { sendiri }\end{array}$ \\
\hline
\end{tabular}




\begin{tabular}{|c|}
\hline Conotative Sign (Tanda Konotatif) \\
\hline Rasa Ketegasan \\
\hline
\end{tabular}

(Sumber. Suryanto. 2018)

Tabel 2 telah diuraikan hubungkait tanda dan penanda berdasarkan Peta Tanda Roland Barthes. Adapun makna denotatif dan konotatif dari tabel 2 sebagai berikut :

a. Makna Denotatif

Pada scene 12 Ayah Maya dan anaknya yakni Maya berdiskusi serta menasehati menganai permasalahan waktu dan biaya Sinamot yang terlahalang dalam perkawinan. Ayah Maya sangat tegas dan komitmen dengan keputusan yang diberikan oleh pasangan Maya yaitu Niko. Hal ini dikarenakan Niko tidak cocok dan hanya bekerja sebagai supir angkot, maka dari itu Ayah Maya menolak untuk memberikannya keringan kembali terhadap waktu dan biaya Sinamot yang harus dipenuhi untuk menikahi Maya.

b. Makna Konotatif

Penanda yang tampak pada film Sinamot di scene 12 menjadi sebuah petanda yang memiliki makna. Pada saat adegan Ayah Maya memberikan penjelasan kepada Maya memperlihatkan penolakan terhadap permohonan yang diberikan terhadap Ayah Maya. Penanda tersebut mengungkap bahwa adat istiadat pada sistem patrilineal adat Batak Toba yang memiliki ketetapan dan ketentuan Sinamot dalam perkawinan adalah pihak perempuan pada masyarakat Batak Toba berdasarkan kesepakatan yang telah dibuat oleh para leluhur dan telah menjadi suatu kebiasaan yang diwariskan oleh masyarakat Batak Toba. Hal ini yang memiliki peranan penting dalam sebuah keluarga adalah kepala keluarga yang bertanggung jawab terhadap keluarganya. Adapun pernyataaan Sersan TB adalah sebagai berikut :

\section{INT.RUANGAN TAMU.RUMAH MAYA-AYAH MAYA}

Maya, bilang sama dia kalau tidak sanggup jangan dipaksa. Apa yang dipaksakan akan berakhir tidak baik. Maya, kau anak kami satu-satunya dan kami mau kau dapat yang terbaik.Bukan seperti Niko.Dia siapa Maya? Bagaimana cara dia untuk mengumpulkan sinamot yang pantas dengan ijazah SMAnya. Bapak yakin setahun pun kita kasih waktu, dia tetap tidak bisa.

Dialog tersebut menggambarkan bahwa orang-orang Batak Toba yang menjadi peran penting dalam sebuah keluarga adalah kepala keluarga. Hal ini dikarenakan kepala keluarga memiliki tanggung jawab yang besar dan anak-anaknya harus mengikuti dan menerima keputusan yang diberikan, sebab seorang bapak ingin melihat pendidikannya bagus serta dapat menjaga nama baik keluarga. Hal ini memang diterapkan oleh masyarakat Batak Toba demi menjaga nama baik keluarga agar terpandang baik dan pendidikan yang tinggi.

Selanjutnya film Toba Dreams menampilkan sistem patrlineal adat Batak Toba pada sebuah keluarga Sersan TB yang sangat memperdulikan masa depan kehidupan anak-anaknya serta bertanggung jawab atas keluarganya. Hal ini dapat dilihat pada tanda Roland Barthes sebagai berikut :

b. Tanda Roland Barthes pada film Toba Dreams Scene 11

Scene 11 telah menggambarkan adegan falsafah kehidupan dalam adat Batak khususnya Batak Toba dengan sistem patrilineal yang terlihat pada tabel sebagai berikut :

Tabel 3. Scene 13 pada saat bapak Sersan TB memberitahukan kepada keluarganya untuk pindah ke kampung halamannya

\begin{tabular}{|l|l|}
\hline Siginified & \multicolumn{1}{|c|}{ Signifier } \\
\hline & $\begin{array}{l}\text { Sersan TB yang kesal karena } \\
\text { mendengar penjelasan Ronggur yang } \\
\text { menolak ajakan Bapaknya yang sesuai } \\
\text { dengan sistem patrilineal mengenai } \\
\text { adat tesebut. }\end{array}$ \\
\hline
\end{tabular}




\begin{tabular}{|c|c|}
\hline $\begin{array}{l}\text { Dialog : Bapaksudahputuskankita semua aka } \\
\text { pindah kekampung halaman dankalianharus iku } \\
\text { karenakalianmasih tanggungjawabbapak. }\end{array}$ & \\
\hline \multicolumn{2}{|c|}{ Denotative Sign } \\
\hline \multicolumn{2}{|c|}{$\begin{array}{l}\text { Ekspresi ketegasan dalam memutuskan sebuah keputusan yang ditunjukkan seorang } \\
\text { Sersan TB dan Keluarganya }\end{array}$} \\
\hline Conotative Signifier (Penanda Konotatif) & Conotative Signified (Petanda Konotatif) \\
\hline $\begin{array}{l}\text { Ungkapan keteguhan Sersan TB yang ingin } \\
\text { mempertahankan untuk pindah bersama } \\
\text { keluarganya untuk kembali ke kampung } \\
\text { halamannya }\end{array}$ & $\begin{array}{l}\text { Sersan TB meluapkan kemarahannya } \\
\text { dengan memukul meja }\end{array}$ \\
\hline \multicolumn{2}{|c|}{ Conotative Sign (Tanda Konotatif) } \\
\hline
\end{tabular}

(Sumber. Suryanto. 2018)

a. Makna Denotatif

Sersan TB berdiskusi dengan keluarganya untuk memberitahukan mengenai permasalahan untuk segera pindah dari Jakarta ke kampung halamannya dikarenakan Sersan TB sudah pensiun dari pekerjaannya sebagai militer. Sersan TB berfikir dengan uang pensiunannya tidak akan cukup untuk menghidupi kehidupannya di Jakarta. Hal ini dikarenakan dikampung memiliki rumah, sawah dan ladang untuk dapat menghidupi keperluan sehari-hari dan hidup nyaman dan bahagia bersama keluarga. Akan tetapi, Ronggur menolak untuk mengikuti keinginan Sersan TB untuk kembali ke kampung halamannya dan lebih baik hidup di Jakarta. Namun, tidak membuat Sersan TB mengubah keputusannya ketika mendengar penjelasan dari Ronggur, Sersan TB tetap komitmen dengan keputusannya kepada keluarganya yang sesuai dengan sistem patrilineal dalam adat Batak Toba .

b. Makna Konotatif

Teknik medium shot dan pada jarak over shoulder terlihat pada penanda di scene 13 yang memberi makna ketegasan Sersan TB terhadap Ronggur beserta keluarganya. Pada saat adegan tersebut Sersan TB menggambarkan suatau kekesalan dan kemarahan dan memukul meja, memperlihatkan bahwa Sersan TB tidak terima dengan ungkapan Ronggur yang menolak ajakan bapaknya untuk pindah kekampung halamannya. Hal ini dikarenakan semua tanggung jawab keluarga kepada Sersan TB sesuai dengan sistem patrilineal adat Batak.

Penanda tersebut mengungkapkan bahwa sistem patrilineal merupakan sistem kekerabatan yang anggota-anggotanya menarik garis keturunan dari pihak laki-laki, serta yang mengatur dan menjadi tanggung jawab keluarga adalah kepala keluarga. Makna penekanan rasa kesal dan komitmen Sersan TB terhadap keputusan yang sudah ditetapkan kepada keluarganya. Dialog yang disampaikan Sersan TB juga memiliki makna bahwa ada aturan adat harus tetap dijaga dan dilestarikan.

c. Peta Tanda Roland Barthes pada film Toba Dreams Scene 40

Sistem patrilineal orang Batak Toba juga tergambar pada scene 40 pada saat Sersan TB berkumpul dengan keluarganya. Sersan TB menjelaskan bahwsanya untuk jenjang pendidikan kedepannya sudah ditentukan oleh Bapaknya. Sumurung dan Taruli sempat menolak permintaan bapaknya tetapi mereka tidak berani untuk mengutarakannya tetapi sebaliknya Ronggur berani menolak perkataan bapaknya tersebut. Hal ini dapat dilihat pada Peta Tanda Roland Barthes scene 40 sebagai berikut : 
Tabel 4. Scene 40 pada saat Sersan TB menentukan pendidikan buat anak-anaknya demi masa depan yang baik

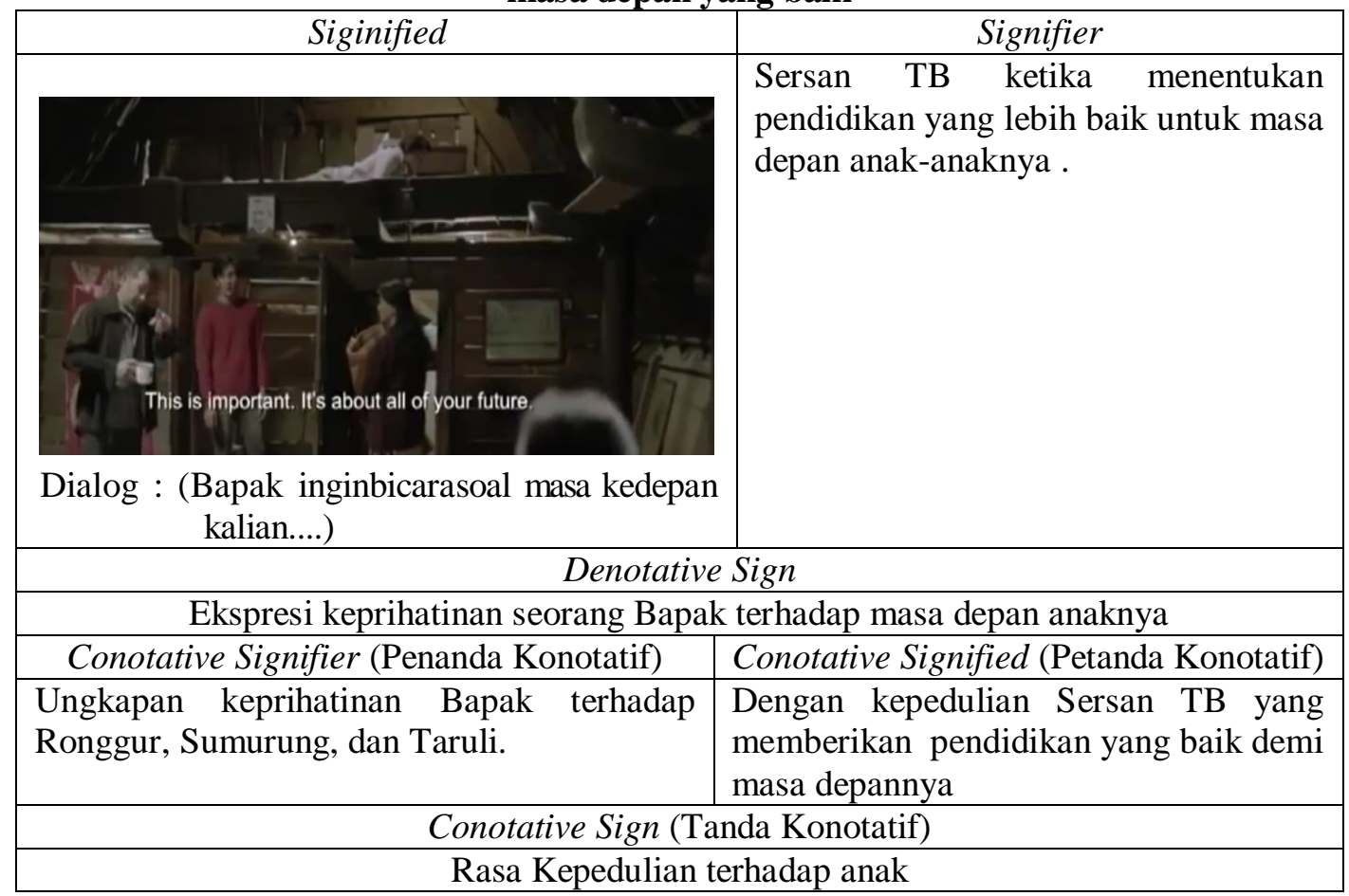

(Sumber. Suryanto. 2018)

Tabel 4 telah menjelaskan penanda dan petanda yang tampak pada scene 40. Maka untuk menjelaskan makna denotatif dan konotatif yang telah diuraikan oleh Roland Barthes adalah sebagai berikut :

\section{a. Makna Denotatif}

Scene 40 terlihat Sersan TB sedang berkumpul dengan keluarganya untuk mendiskusikan mengenai pendidikan yang pantas buat kalian kepada anak-anaknya. Sersan TB sudah memasukkan daftar anaknya dipendidikan masing-masing yang dimana Sumurung dimasukkan disekolah akademi militer dan Taruli di masukkan sekolah SMA 2 Yayasan Soposurung. Ketika Sumurung mendengar dimasukkan ke sekolah akademi militer tergambar ingin menolak tetapi tidak berani untuk membicarakannya, hal ini hamper sama dengan Taruli yang tidak ingin mengecawakan Bapaknya. Namun, Ronggur menolak dan membantah tidak ingin menuruti keputusan bapaknya yang ingin dimasukkan ke pendidikan pendeta untuk meneruskan tradisi keluarga. Sersan TB membuat keputusan ini untuk masa depan anaknya yang lebih baik dan dapat membanggakan orang tua serta menjaga nama baik keluarga.

b. Makna Konotatif

Penanda yang tampak pada film Toba Dreams pada scene 40 menjadi sebuah petanda yang memiliki makna. Sersan TB sangat memperdulikan anak-anaknya ketika pindah ke kampung halamannya terutama dalam pendidikan. Hal ini dapat dilihat saat Sersan TB memberitahukan mengenai pendidikan bagi anak-anaknya. Kemudian teknik medium long shot dipergunakan untuk memperlihatkan seseorang dari bawah lutut sampai atas serta memperlihatkan kondisi sekitar Sersan TB dan keluarga yang berada didalam rumah. Teknik medium long shot dipergunakan untuk memperlihatkan penekanan pada pernyataan Sersan TB terhadap keluargnya dan juga membentuk suasana keramaian didalam rumah. Adapun pernyataaan Sersan TB adalah sebagai berikut :

\section{INT.RUMAH OMPUNG BORU-SIANG}

Sersan TB :

Taruli dan Sumurung sudah lulus SMP dan SMA, kalau Sumurung sudah bersedia masuk akedemi militer.. lanjutkan cita cita ayah dulu yang tak kesampaian sekolah perwira. Sementara Taruli,daftar ke SMA 2 yayasan soposurung,salah satu sekolah terbaik di indonesia. 
Sersan TB :

Dan kau Ronggur, Untuk kebaikanmu, Ayah ingin kamu meneruskan tradisi keluarga kita, ayah ingin kamu kamu sekolah pendeta. Itu pilihan yang paling tepat untuk menyelamatkan hidupmu.

Dialog tersebut menggambarkan bahwa orang-orang Batak Toba yang menjadi peran penting dalam sebuah keluarga adalah kepala keluarga. Hal ini dikarenakan kepala keluarga memiliki tanggung jawab yang besar dan anak-anaknya harus mengikuti dan menerima keputusan yang diberikan, sebab seorang bapak ingin melihat pendidikannya bagus serta dapat menjaga nama baik keluarga. Hal ini memang diterapkan oleh masyarakat Batak Toba demi menjaga nama baik keluarga agar terpandang baik dan pendidikan yang tinggi. Penggambaran pada tokoh dalam film Toba Dreams memberikn suatu ciri khas identitas mengenai masyarakat Batak Toba. Seperti halnya yang disampaikan oleh Sal Murgianto bahwa tradisi merupakan latar perkembangan kebudayaan yang member cirri khas identitas atau kepribadian suatu bangsa (Sal Murgianto, 2004: 15)

Teknik medium close up dipergunakan untuk memperlihatkan ekspresi dari tokoh Sumurung dan Sersan TB, Sumurung berbicara terhadap bapaknya mengenai penolakan untuk tidak masuk sekolah militer dan ingin menjadi seorang pendeta dalam meneruskan tradisi keluarga. Adegan tersebut diambil dari dada sampai kepala pemain yang terlihat pada gambar dibawah ini :

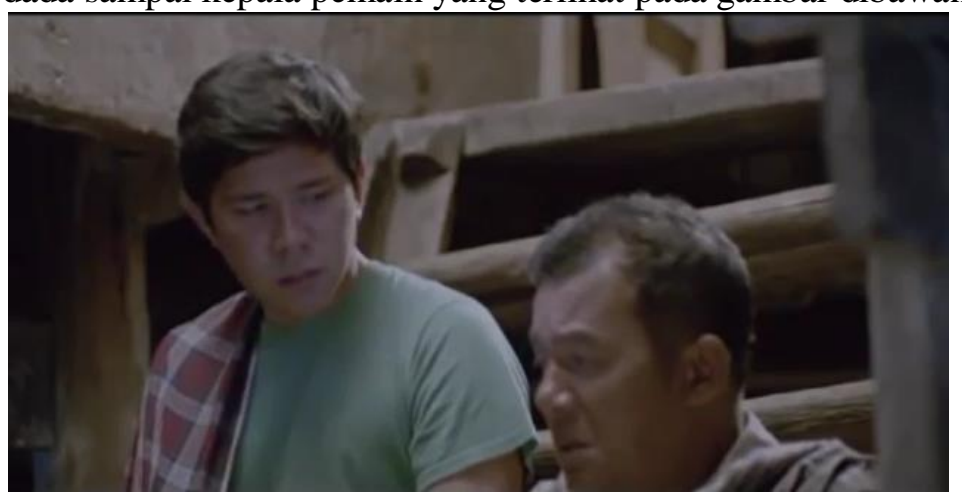

Gambar 17. Sumurung ingin sekolah sebagai pendeta kepada Bapaknya

(Sumber. Suryanto. Capture film Toba Dreams. 2018)

Kemudian film Mursala yang mengenai permasalahan perkawinan yang disebabkan oleh ikrar janji atau tidak boleh menikah sesama marga. Hal ini tidak lepas dari peranan orang tua terutama yakni ayah atau kepala keluarga. Sistem partilineal ini sangat jelas pada film Mursala ketika sebuah aturan harus ada persetujuan dari pihak laki-laki dan perempuan, Hal ini terlihat pada tanda Roland Barthes sebagai berikut :

d. Tanda Roland Barthes pada film Mursala Scene 50

Scene 40 juga memperlihatkan adanya sistem patrilineal. Hal itu terlihat ketika Anggiat memohon kepada Amung agar diberi izin untuk nikah dengan Clarisa yang terhalang oleh adat atau se-marga. Sistem patrilineal tersebut dapat dilihat pada Peta Tanda Roland Barthes scene 50 sebagai berikut :

Tabel 5. Scene 50 Amung diskusi bersama Anggiat

\begin{tabular}{|l|l|}
\hline \multicolumn{2}{|c|}{ Siginified } \\
\hline $\begin{array}{l}\text { Amung ketika menjelaskan bahwa } \\
\text { dirinya tidak bisa dapat membantu dan } \\
\text { meresteui Anggiat dan Clarsia }\end{array}$ \\
\hline \multicolumn{2}{|c|}{ Dialog : Pastiada,Nak...Tapiapakamu } \\
maumelanggar?
\end{tabular}




\begin{tabular}{|l|l|}
\hline \begin{tabular}{|l|l|}
\hline Conotative Signifier (Penanda Konotatif) \\
Angkapan keprihatinan Amung terhadap
\end{tabular} & $\begin{array}{l}\text { Conotative Signified (Petanda Konotatif) } \\
\text { tidak bisa berbuat banyak membantu } \\
\text { Anggiat }\end{array}$ \\
\hline \multicolumn{3}{|c|}{ Conotative Sign (Tanda Konotatif) } \\
\hline \multicolumn{3}{|c|}{ Rasa ketidakberdayaan terhadap adat } \\
\hline
\end{tabular}

(Sumber. Suryanto. 2018)

Tabel 5 telah menjelaskan penanda dan petanda yang tampak pada scene 40. Maka untuk menjelaskan makna denotatif dan konotatif yang telah diuraikan oleh Roland Barthes adalah sebagai berikut :

a. Makna Denotatif

Scene 50 terlihat Anggiat menemui Amung dan meminta bantuan denganya memohon meminta merestui pernikahan dengan Clarisa. Akan tetapi, Amung tidak dapat membantu Anggiat untuk meresteui hubunganya dengan Clarisa karena opungnya tidak dapat melanggar adat istiadat para leluhur. Anggiat tetap membujuk opung untuk dapat merestui dan membantunya. Namun Amungmenolak dan ingin mengikuti adat istiadat orang Batak yang telah dibuat sejak dahulu.

b. Makna Konotatif

Teknik medium close up terlihat pada penanda di scene 50 yang memberi makna kedekatan hubungan Anggiat dengan Amung. Pada adegan tersebut menggambarkan suatu ketidakberdayaan Anggiat dalam menentang adat sehingga Anggiat meminta bantuan kepada Amung. Anggiat berharap Amung dapat membantu dan memberi solusi mengenai hubungannya. Namun Amung menolak dan melarang Anggiat untuk menikah. Hal ini diperjelas dengan adanya dialog sebagai berikut :

\section{INT.GEREJA-MALAM}

Amung

Buat agama, ini tidak menjadi masalah Anggiat, tapi bentuk dari kita menghargai leluhur adalah mengikuti adat yang sudah mereka tentukan.

Dialog tersebut menggambarkan bahwa orang-orang Batak Toba lemah terhadap hukum adat yang telah dibuat oleh para leluhur. Tetapi orang-orang Batak Toba tersebut mencerminkan masih sangat menghormati para leluhurnya. Penggambaran pada tokoh film Mursala memberikan suatu ciri khas identitas mengenai masyarakat Batak Toba. Seperti halnya yang disampaikan oleh Sal Murgianto bahwa tradisi merupakan akar perkembangan kebudayaan yang memberi ciri khas identitas atau kepribadian suatu bangsa (Sal Murgianto, 2004: 15).

e. $\quad$ Peta Tanda Roland Barthes pada film Mursala scene 79

Pada scene 79 terlihat adegan ketidakberdayaan Anggiat untuk menentang dan memohon untuk dapat melaksanakan pernikahan antara Anggiat dan Clarisa dalam sistem patrilineal. Sikap tersebut terlihat pada tabel 6 sebagai berikut :

Tabel 6. Anggiat betemu dengan Ayah Clarisa

\begin{tabular}{|c|c|}
\hline Siginified & Signifier \\
\hline 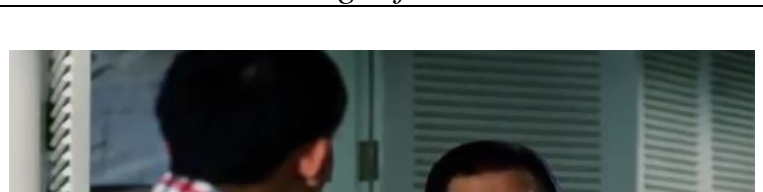 & $\begin{array}{l}\text { Ayah Clarisa ketika menjelaskan } \\
\text { bahwasannya tidak bisa membantu } \\
\text { Anggiat untuk melaksanakan } \\
\text { pernikahannya. }\end{array}$ \\
\hline $\begin{array}{c}\text { Dialog : Yah,karena kitaharusmenghormatiadat } \\
\text { leluhurkita,Gi. }\end{array}$ & \\
\hline \multicolumn{2}{|c|}{ Denotative Sign } \\
\hline Ekspresi keprihatinan seorang Ayah & erhadap masa depan anaknya \\
\hline Conotative Signifier & Conotative Signified (Petanda Konotatif) \\
\hline
\end{tabular}




\begin{tabular}{|l|l|}
\hline \multicolumn{1}{|c|}{ (Penanda Konotatif) } & \\
\hline $\begin{array}{l}\text { Ungkapan keprihatinan dan kepedulian Ayah } \\
\text { Clarisa terhadap Anggiat dan Clarisa untuk tidak } \\
\text { dapat dan melarang pernikahan itu terjadi }\end{array}$ & $\begin{array}{l}\text { Dengan ketidakberdayaan Ayah Clarisa } \\
\text { tidak dapat membantu }\end{array}$ \\
\hline \multicolumn{2}{|c|}{ Conotative Sign (Tanda Konotatif) } \\
\hline \multicolumn{2}{|c|}{ Rasa Kesedihan } \\
\hline
\end{tabular}

(Sumber. Suryanto. 2018)

Tabel 6 telah menjelaskan penanda dan petanda yang tampak pada scene 79. Maka untuk menjelaskan makna denotative dan konotatif yang telah diuraikan oleh Roland Barthes adalah sebagai berikut :

a. Makna Denotatif

Anggiat menemui Ayah Clarisa dan meminta bantuan dengannya untuk dapat bertemu dengan keluarga Anggiat di desa. Akan tetapi, Ayah Clarisa tidak dapat membantu Anggiat untuk bertema dengan keluarganya karena ayahnya tidak mau melanggar aturan adat para leluhur. Anggiat tetap membujuk ayah Clarisa untuk mau menemui keluarganya di desa. Namun, ayah Clarisa menolak dan ingin mengikuti adat istiadat orang Batak yang telah dibuat sejak dahulu serta melarang Anggiat untuk menikahi anaknya. Hal ini dikarenakan untuk masa depan anaknya dan menjaga nama baik keluarga.

b. Makna Konotatif

Teknik medium close up terlihat pada penanda di scene 78 yang member makna kedekatan hubungan Anggiat dengan Ayah Clarisa. Pada adegan tersebut menggambarkan suatu ketidakberdayaan Anggiat dalam menentang adat sehingga Anggiat meminta bantuan kepada Ayah Clarisa. Anggiat berharap Ayah Clarisa dapat membantu dan member solusi mengenai hubungannya. Ayah Clarisa yang tinggal pada budaya yang berada seperti yang digambarkan pada film Mursala yaitu Jakarta biasanya memiliki pemikiran-pemikiran yang berbeda dan bersifat modern. Tapi kenyataannya terbalik yang disampaikan pada film Mursala karena Ayah Clarisa juga sependapat dengan larangan adat tersebut. Hal ini diperjelas dengan adanya dialog sebagai berikut :

\section{INT.RUMAHCLARISA-MALAM}

\section{AYAH CLARISA}

Berkat masalah ini, Om sekarang mulai lagi mempelajari adat kita. Yah, karena kita harus menghormati adat leluhur kita.Om juga tidak bias berbuat banyak untuk itu.

Dialog tersebut menggambarkan bahwa orang-orang Batak Toba lemah terhadap hokum adat yang telah dibuat oleh para leluhur. Tetapi orang-orang Batak Toba tersebut mencerminkan masih sangay menghormati para leluhurnya.

Film Anak Sasada menceritakan sebuah sistem patrlineal yang berada dikota perantauan dan bukan kepada hal ayah yang harus bertanggung jawab melainkan sebuah aturan panggilan kekerabatan yang sesauai dengan dari garis keturunan keluarga. dan yang terdapat suatu sistem patrilineal didalam cerita dan selain sebagai seni tontonan yang dilihat sebagai hiburan seluruh masyarakat. Namun, penggunaan tanda dipakai untuk sebuah pengungkapan makna yang membentuk sebuah konsep cara masyarakat mewariskan adat leluhurnya.

f. $\quad$ Peta Tanda Roland Barthes pada film Anak Sasada Scene 27

Permasalahan mengenai kemiskinan dan pendidikan juga tampak pada saat Sabungan pergi merantau ke kota Medan yang disebabkan tulangnya yang memerintahkan Sabungan untuk merantau dan dikampungnya hanya dirumah tanpa bekerja. Tibanya Sabungan di kota Medan berjumpa dengan temannya yang juga bersuku Batak yaitu Pastima yang menjelaskan aturan adat sistem patrilineal mengenai seorang yang merantau meninggalkan kampung halamannya. Hal ini dapat dilihat pada Peta Tanda Roland Barthes pada film Anak Sasadascene 27 sebagai berikut :

Tabel 7. Pastima memberitahu mengenai tutur kekerabatan adat ketika sedang diperantauan

\begin{tabular}{|l|l|}
\hline Siginified & \multicolumn{1}{|c|}{ Signifier } \\
\hline & Pastima yang peduli ketika menjelaskan \\
& mengenai tutur kekerabatan adat dikota \\
& perantauan. Sedangkan Sabungan \\
& memperlihatkan ekspresi bingung \\
\hline
\end{tabular}




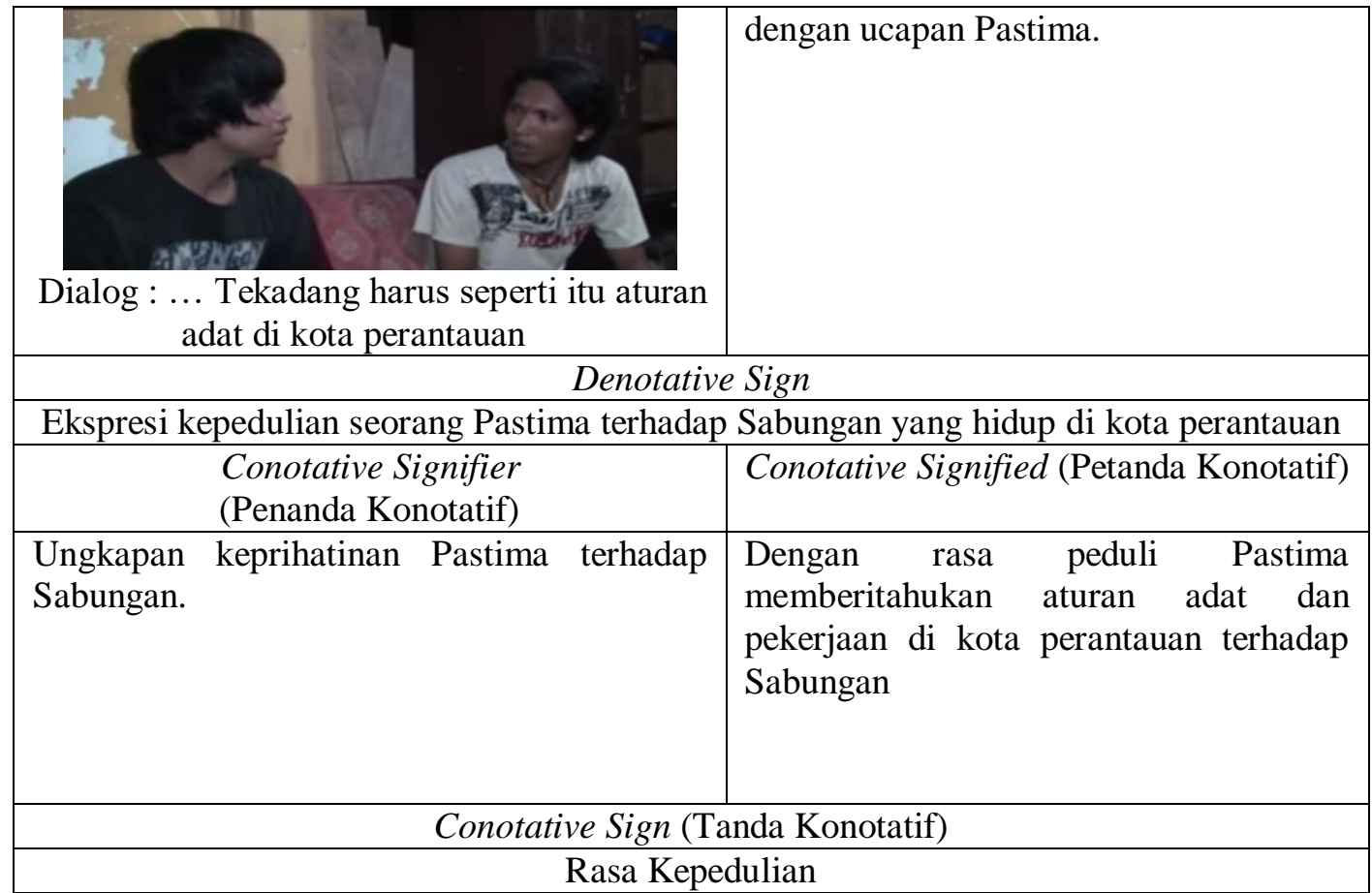

(Sumber. Suryanto. 2018)

Tabel 7 telah menjelaskan mengenai hubungkait antara tanda dan penanda berdasarkan Peta Tanda Roland Barthes. Adupun makna denotative dan konotatif dari tabel 7 adalah sebagai berikut : a. Makna Denotatif

Pada scene 27 terlihat Pastima dan Sabungan sedang berbicara mengenai tutur kekerabatan yang ada dikota dan berbedea dengan dikampung. Sabungan yang tidak mengetahui aturan mengenai tutur kekrabatan yang ada dikota hanya diam dan bingung. Pastima yang menerima Sabungan untuk tinggal dirumah bersamanya dikarenakan Sabungan tidak memiliki tempat tinggal dan pekerjaan. Selama Sabungan tinggal ditempat Pastima, Sabungan harus menuruti dan mengetahui aturan dirumah ini mulai dari sikap, tata keramah dan tutur kekerabatan. Hal ini juga disampaikan oleh Pastima mengenai tinggal dikota perantauan yakni tidak sedikit orang meninggal ketika mencari kerja dikota, kemudian kemanapun mencari kerja pandai-pandailah membawa diri kepada Sabungan.

b. Makna Konotatif

Teknik medium close up terlihat penanda di scene 20 yang memberi makna kedekatan Pastima dan Sabungan. Pada adegan tersebut menggambarkan suatu kepedulian Pastima dalam aturan adat di kota perantauan dikarenakan Sabungan yang tidak mengetahui banyak aturan adat dikota dan Sabungan yang tidak memiliki keahlian hanya bermodal ingin merantau. Pastima hanya bisa membantu Sabungan dengan memberi tempat tinggal dan makan. Pastima yang tinggal pada budaya yang berbeda seperti yang digambarkan pada film Anak Sasada yaitu Medan biasanya memiliki pemikiran-pemikiran yang berbeda dan bersifat modern. Kemudian Pastima juga memberi nasehat terhadap Sabungan ketika tinggal diperantauan harus bisa beradaptasi dan mengerti atura didalam kota perantauan. Hal ini diperjelas dengan adanya dialog sebagai berikut :

\section{INT. RUMAH PASTIMA.MALAM}

PASTIMA

Selama tinggal dirumah ini anggaplah aku seperti abangmu, begitulah seharusnya terhadap tuan rumah. Terkadang harus seperti apabila kita diperantauan. Tutur kekerabatan dikampung itu karena adat tapi keberadaan kita dikota ini bukan karena adat.

Dialog tersebut menggambarkan bahwa orang-orang Batak Toba lemah terhadap hukum adat yang telah dibuat para leluhur. Tetapi orang-orang Batak Toba tersebut mencerminkan masih sangat menghormati para leluhurnya. Pastima yang memberitahukan mengenai aturan tutur kekerabatan tehadap Sabungan dikarenakan tutur kekerabatan dikampung diberbeda dengan dikota, Sabungan selama tinggal di kota perantauan tidak boleh memanggil Lae (panggilan laki-laki) oleh teman 
bukan satu marga-nya Pastima. Hal ini disebabkan Lae merupakan suatu panggilan yang biasa dikehidupan suku Batak Toba dan berlaku untuk panggilan dari saudara ipar dari pihak istri atau suami jika mempunyai saudara laki-laki. Sabungan hanya boleh panggil dengan sebutan abang terhadap Pastima.

Roland Barthes menguraikan bahwa tanda konotatif tidak sekedar memiliki makna tambahan, namun juga mengandung kedua bagian tanda yang melandasi keberadaanya. Dalam keragka Roland Barthes, konotasi identik dengan operasi ideologi yang disebutnya sebagai mitos dan berfungsi untuk mengungkapkan dan memberikan pembenaran bagi nilai-nilai dominan yang berlaku dalam suatu periode tertentu.

Simbol-simbol yang ditemukan dalam film Sinamot, Toba Dreams,Mursala, dan Anak Sasada menunjukkan bahwa terdapat sebuah aturan adat Batak Toba yang dikenal dengan sistem patrilineaal. Simbol tersebut terlihat dalam beberapa scene yang telah dimaknai secara denotatif dan konotatif sehingga memunculkan sebuah mitos. Hal ini juga dijelaskan dalam Sobur bahwa mitos merupakan sebuah cerita dimana suatu kebudayaan menjelaskan atau memahami beberapa aspek dari realitas alam. Mitos menurut Barthes merupakan sebuah budaya cara berfikir tentang sesuatu, cara mengonseptualisasi atau memahami hal tersebut (Alex Sobur, 2003: 69). Sementara pada film Mutiara Dari Toba tidak terdapat sebuah sistem patrilineal karena lebih menggambarkan wisata kebudayaan dan sebagainya. Mitos yang terdapat dalam masyarakat Batak Toba digambarkan dalam film Sinamot, Toba Dreams,Mursala, dan Anak Sasada dan membentuk sebuah aturan adat mengenai sistem patrilineal :

1. Masyarakat Batak Toba menganut sistem kekerabatan patrilineal. Di mana garis keturunan ditentukan berdasarkan dari pihak ayah. Laki-laki mempunyai peranan yang sangat vital dalam menentukan otonomi dalam suatu kerabat. Bahkan menurut sistem patrilineal, kedudukan pria lebih bertanggung jawan besar pengaruhnya dalam sebuah keluarga yakni hal menjaga nama baik keluarga, menentukan kebijakan yang diatur oleh ayah sebagai kepala keluarga, mematuhi keputusan yang diberikan ayahnya kepada keluarganya dan menentukan kebahagian masa depan anak-anaknya. Bahkan masyarakat Batak Toba mempunyai sistem kepercayaan pada umumnya bergama Nasrani.

2. Masyarakat Batak Toba juga mempercayai bahwa dengan mengikuti adat istiadat pada sistem patrilineal kehidupan adat Batak Toba maka masyarakat tersebut menghargai para leluhurnya dan mendapat keberkahan.

3. Pada sistem patrilineal pada masyarakat Batak Toba mempunyai generasi sesorang mendapat perhatian istemewa dalam kehidupan sehari-hari serta masyarakat Batak Toba memperhatikan dengan baik siapa yang segenerasi dengan dirinya dalam lingkungan kahanggi (keluarga semarga) maupun dalam kekerabatan Dalihan Na Tolu (keluarga besar) begitu pula dengan orang tuanya, kakeknya dan seterusnya. Akan tetapi berbeda dengan di kota perantauan, apabila tutur kekerabatan dikampung itu karena ikatan adat tetapi keberadaan dikota bukan karena adat.

\section{PENUTUP}

Berdasarkan uraian yang telah peneliti jabarkan sebelumnya, peneliti menyimpulkan bahwa Fenomena lima film yang berlatar budaya Batak Toba yakni film Sinamot, Toba Dreams, Mursala, Anak Sasada dan Mutiara Dari Toba. Kelima film tersebut menggambarkan budaya Batak Toba seperti Dalihan Na Tolu, Sistem patrilineal, Tradisi merantau dan Sistem kepercayaan. Konsep yang sangat mendasar dari sistem kekerabatan ini adalah marga. Semua anggota dari satu marga memakai satu identitas yang dibubuhkan sesudah nama kecilnya, nama marga itu merupakan pertanda bahwa orang-orang yang menggunakannya masih mempunyai kakek yang sama. Secara logis tidak dapat terperinci rentetan leluhur atau kakek yang menghubungkan orang-orang se-marga dengan kakek yang sama, namun ada suatu keyakinan bahwa orang-orang yang menggunakan nama marga tersebut terjalin oleh hubungan darah. Penentuan kedudukan yang ditimbulkan berdasarkan marga membuat sesorang akan terikat kepada adat istiadat yang disebut dengan Dalihan Na Tolu.

Setiap fenomena film berlatar budaya Batak Toba yang terdapat Dalihan Na Tolu pada film Sinamot, Mursala dan Mutiara Dari Toba. Selanjutnya pada fenomena sistem patrilineal yang terdapat dalam film Sinamot, Toba Dreams, Mursala, dan Anak Sasada. Tradisi merantau adat Batak Toba menjadi sebuah fenomena film berlatar budaya Batak Toba, tetapi hanya dua film yang 
terdapat tradisi merantau dari kelima film tersebut yakni film Mursala dan Anak Sasada. Terakhir pada sistem kepercayaan adat Batak Toba yang terdapat dalam film berlatar budaya Batak Toba yakni film Sinamot, Toba Dreams dan Mutiara Dari Toba.

\section{DAFTAR PUSTAKA}

Arivia.Gadis. 2006.Feminisme: Sebuah Kata Hati. Jakarta : Penerbit Kompas. Politik Media. Yogyakarta: LKiS

Astuti.2015. Analisis Pengaruh Bahan Tambah Kapur Terhadap karakteristik RAP (Reclaimed Asphalt Pavement), Tugas Akhir, Universitas Muhammadiyah Surakarta, Surakarta.

Bungin, Burhan.2007.Penelitian Kualitatif: Komunikasi, Ekonomi, Kebijakan Publik dan Ilmu Sosial lainnya.Jakarta:Putra Grafika

Diana Markimbunan. 1973. Simbol dan Perlambang Warna, Sebuah Pengantar Kriya Seni Memahami Kode dan Lambang dalam Masyarakat. Surakarta: Universitas Negeri Sebelas Maret. Hal 34

Fomm, Erich. 2001. Akar Kekerasan, Analisis Sosio-Psikologis atas Watak Manusia, hal 146.

Hariyanto. 2009. Gender dalam Konstruksi Media. Jurnal Komunika. STAIN Purwokerto.

Mulyana, Deddy. Ilmu Komunikasi: Suatu Pengantar. Cetakan ke 18. Bandung: PT. Remaja Rosdakarya, 2014

Rohandika, Cahyo. 2011. Takut : Kaleidoskop Film Horor Indonesia. Jakarta : Kepustakaan Populer Gramedia., hal. 59

Sears, David O dkk, 1999, Psikologi Sosial, P.T Gelora Aksara Pratama, Jakarta

Sobur, Alex, 2003, Semiotika Komunikasi, P.T Rosdakarya, Bandung

Sumarno, Marselli, 1966, Dasar-Dasar Apresiasi Film, Gramedia Widiasarana, Jakarta

Stephanus Hermawan Susanto . (2011), Mudah Membuat Aplikasi Android., C.V ANDI OFFSET, Yogyakarta

Wibowo (2011).Manajemen Kinerja. Jakarta : PT. Raja Grafindo Persada

Yusuf Amir Pilang. 2012. Semiotika dan Hipersemiotika: Kode, Gaya, dan Matinya Makna. Edisi Keempat. Bandung: Matahari. Hal. 238 - 239. 